\title{
To Be Happy: A Case Study of Entrepreneurial Motivation and Entrepreneurial Process from the Perspective of Positive Psychology
}

\author{
Xiaohua Su ${ }^{1}$, Shengmei Liu ${ }^{1}$, Shujun Zhang ${ }^{2, * \mathbb{D}}$ and Lingling Liu ${ }^{2}$ \\ 1 School of Management, Jinan University, Guangzhou 510000, China; tmnsxh@jnu.edu.cn (X.S.); \\ senmeini1206@stu2018.jun.edu.cn (S.L.) \\ 2 School of Business, Sun Yat-sen University, Guangzhou 510000, China; Lingling.Liu@cn.ab-inbev.com \\ * Correspondence: mnszsj@mail.sysu.edu.cn; Tel.: +86-020-84114136
}

Received: 5 December 2019; Accepted: 9 January 2020; Published: 13 January 2020

check for updates

\begin{abstract}
The pursuit of wealth maximization is considered to be the greatest driving force of entrepreneurship. However, this economic rational perspective cannot sufficiently answer why potential or continuous entrepreneurs still choose entrepreneurship or even continuous entrepreneurship in the face of high failure rate and tremendous uncertainty. On the basis of the dynamic process of entrepreneurship and the perspective of positive psychology, this study attempts to interpret the sustained motivation mechanism of entrepreneurs. This study uses multiple cases to investigate the emotion, cognition, and behavior of entrepreneurial process. Through NVivo software and emotion dictionary, more than 27,000 micro blogs (Weibo) of six entrepreneurs were analyzed, and the model of positive emotion in entrepreneurial process was constructed. The findings are as follows. (1) In the process of establishing a business, entrepreneurs can persist in a highly uncertain environment by acquiring positive emotions. That is, the motivation of sustainable entrepreneurship originates from the emotion of happiness and satisfaction that entrepreneurs obtain. (2) Positive emotions affect the formation and expansion of key activities of entrepreneurship through cognition and then persist with entrepreneurship. Specifically, positive emotion promotes the formation of entrepreneurial intention by expanding cognitive structure, intuitive processing, and analytical processing to promote the acquisition of entrepreneurial resources and the expansion of entrepreneurial ability. (3) In the process of entrepreneurship, emotional return is a performance dimension parallel to economic return. This conclusion provides a new perspective towards revealing the entrepreneurial motivation of entrepreneurs in highly ambiguous environments.
\end{abstract}

Keywords: entrepreneurial motivation; entrepreneurial cognition; positiveemotion; entrepreneurship insist

\section{Introduction}

Entrepreneurship is not only an important driving force for economic growth and industrial transformation, but also for the growth of employment opportunities [1], as well as an important way for individuals to achieve growth, especially for economies in transition, such as China [2]. Startups are often the main source of economic growth in emerging economies; thus, encouraging entrepreneurship is a strategic policy for the majority of developing countries [3]. However, according to the Global Entrepreneurship Monitor 2017-2018 report of China, the survival rate of new startups in China is only $5-25 \%$, or even lower; more than half of them fail within three years. In addition, startups in developed countries, such as the UK and the US also face similar situations, where only $7 \%$ of startups have turnover of more than 10,000 pounds [1]. Apparently, entrepreneurship holds extensive uncertainty and faces high failure rate. The instability of income and great work intensity cause the majority of 
entrepreneurs to quit halfway [4]. Only a small number of new entrepreneurs persist and ultimately succeed. Remaining with or forsaking entrepreneurship is a dilemma for new entrepreneurs. Thus, an interesting question arises: why do so many new entrepreneurs continue and remain with the front line of entrepreneurship despite the highly uncertain outlook, and the fact that early economic benefits are not evident?

To solve this problem, from the perspective of cost-benefit, traditional economics views entrepreneurial activities with economic rationality and regards entrepreneurship as the way to obtain personal excess wealth [5]. However, maximizing wealth is not the only driving force for entrepreneurship. Non-economic motivations, such as autonomy, are believed to compensate for reduced income levels [6,7]. In addition, research on new economic sociology has over-socialized entrepreneurial activities, which are considered a way of arbitrage of individual social capital system or an important means for the low-end society to break through the social stratum in the transitional economy [8]. Some scholars have also emphasized that the entrepreneurial process has contextual dependence, and they have explored the social significance of entrepreneurship from the perspective of institutional entrepreneurship [9]. However, wealth or social symbols entailed by entrepreneurial activities are the result of hindsight. Given the high risk and failure rate of entrepreneurship, entrepreneurs are self-driven by entrepreneurial spirit; however, existing studies have failed to perform an in-depth analysis of this problem, most of which are still studying entrepreneurial activities from the perspective of wealth creation [10].

With the concern of non-economic motivation in entrepreneurial behavior, studies on entrepreneurial emotion are gradually emerging in the field of entrepreneurial research. Scholars believe that emotion plays a key role in entrepreneurial cognition and explain how emotion affects entrepreneurial behavior intention [11]. The entrepreneurial process is accompanied by a high degree of positive and negative emotions; thus, these emotions will interact with confidence, thereby affecting entrepreneurial motivation. Furthermore, scholars have focused on the role of positive emotions (e.g., happiness) in entrepreneurial behavior. Happiness affects entrepreneurial performance [12], and individual entrepreneurial enthusiasm contributes to opportunity identification and productive use of opportunities [11,13]. However, existing research on the subjective utility of entrepreneurship, such as the influence of positive emotional experience on entrepreneurship persistence, remains lacking. Therefore, to understand the motivation and continuous power source of entrepreneurs in the process of entrepreneurship, the methods they adopt in handling high risk and failure rate of entrepreneurship and the mechanism of positive emotions in different entrepreneurial stages should be urgently identified.

On the basis of the aforementioned theoretical and practical background, this study attempts to answer the following questions: why do some entrepreneurs persist or even continue to transact business in the face of uncertainty and setbacks in the process of entrepreneurship, whereas others decide to surrender? What role does entrepreneurial emotion play in the decision-making process of entrepreneurship? To explore these issues, this study aims to explore the change of entrepreneurs' emotion and behavior in the process of entrepreneurship, from the perspective of positive psychology and economic management through a case study of six entrepreneurs in different industries. This study focuses on the interpretation of the source of continuous motivation of entrepreneurs and the mechanism of positive emotion to help entrepreneurs overcome the difficulties and advance into a dynamic and challenging entrepreneurial process.

\section{Theoretical Background}

\subsection{Entrepreneurial Motivation}

The entrepreneurial process begins with the identification and assessment of opportunities [2], which involve organizational resource development and value creation. Entrepreneurial motivation is a type of internal and external driving force of a series of behaviors that entrepreneurs perform in the process [14]. Motivation in entrepreneurial literature has developed along a path similar to 
that in organizational psychology. The discussion of entrepreneurial motivation has evolved from static, content-oriented theory to dynamic, process-oriented theory [15]. With regard to the trigger mechanism of entrepreneurial motivations, scholars have attempted to explain from two perspectives, namely, economic and non-economic motivations. Alan et al. (2011) proposed that entrepreneurial motivation theory can be divided into two schools in essence, one is based on economics, and the other is rooted in psychology; the two schools have conflicting views. Classical economic theory holds that entrepreneurial behavior always aims at maximizing wealth, and pursuing economic returns is the main driving force of entrepreneurial behavior [16,17]. Specifically, potentially high economic returns can 'pull' individuals to start a business, and the lack of sufficient economic returns (such as income solidification) will 'push' individuals to start a business [18,19]. Hessels et al. (2008) reported that the formation of entrepreneurial motivation largely depends on the desire of entrepreneurs to increase wealth [20]. From the perspective of expected return, Praag and Cramer (2001) found that if the expected return on entrepreneurship exceeds the employment wage, entrepreneurial motivation will arise [21]. However, entrepreneurship is a complex activity, and this view fails to explain several phenomena of the entrepreneurial process. Firstly, despite the high risk of obtaining economic returns, why do people pursue to start a business as a career? Secondly, individuals experience no profit or even sustained losses in the early stage of entrepreneurship. Why do some entrepreneurs still insist on starting a business? Evidently, simply pursuing wealth does not lead to entrepreneurial behavior.

The shift from economic to non-economic motivation not only implies the complexity of the source of entrepreneurial motivation but also emphasizes the important role of non-economic motivation in the career choice, persistence and exit of entrepreneurs and their success. Rindova et al. (2009) believed that entrepreneurial motivation stems from the realization of self-worth, and personal achievement should play an important role in entrepreneurial behavior and decision making [10]. Entrepreneurial motivation is also influenced by individual situation and external environment, such as unemployment, previous work experience, resource availability, and government influence [22]. However, some scholars have indicated that these factors have little influence on entrepreneurial motivation [23]. Given the altruism and pro-social motivation, people are motivated to identify and utilize potential opportunities that can solve social problems and develop society [24]. Some scholars have also suggested that the negative health status of individuals will also lead them to choose entrepreneurship as a career because they often attach great importance to autonomy $[20,25,26]$. The intrinsic characteristics of entrepreneurs, such as self-efficacy and values, will also affect their entrepreneurial motivation [22,27]. Gerry et al. (2005) discussed the source of entrepreneurial motivation from two aspects of risk preference and entrepreneurial feasibility analysis based on behavior and process orientations. Individuals with entrepreneurial self-efficacy overflow with confidence in entrepreneurial results; thus, they believe that entrepreneurship is feasible. They also indicated that the risk tolerance of entrepreneurs is positively related to their entrepreneurial motivation [22].

The entrepreneurial process holds immense uncertainty [28]; thus, the fear of failure may reduce the willingness of entrepreneurs. However, individuals with strong enthusiasm for an activity are more likely to continue to pursue and participate in the activity $[29,30]$. Therefore, research on entrepreneurs' happiness in entrepreneurial behavior is different from the rational decision making and simple money preference in traditional economics, which also makes scholars gradually pay attention to the importance of entrepreneurs obtaining subjective emotional experience in the process of entrepreneurship [31]. The harvest of happiness in entrepreneurial practice is a major source of entrepreneurial motivation. In addition, given the dynamic nature of the entrepreneurial process, entrepreneurs are faced with a high degree of uncertainty. Thus, the entrepreneurial motivation may be modified, but it will change with the environment and entrepreneurial cognition.

On the basis of mainstream entrepreneurial motivation research, most scholars have viewed entrepreneurial activities with economic rationality. However, the economic motives do not clarify why entrepreneurs will make sustained efforts when high uncertainty exists and future income is indefinite. As the compensation of economic motivation, non-economic motivation explains entrepreneurial 
persistence to a certain extent. However, the duration and intensity of entrepreneurial motivation and how the subjective experience of entrepreneurs (especially positive emotions) can play a role in the process of entrepreneurship remain unclear. The existing research on entrepreneurial motivation is more static than dynamic. On the basis of the continuous changes of environmental, organizational and individual factors, this study investigates entrepreneurial motivation based on the different stages of entrepreneurship.

\subsection{Entrepreneurial Cognition}

The theory of entrepreneurial cognition holds that the important reason for the success of entrepreneurs is that they have more reasonable entrepreneurial cognition. Entrepreneurial cognition refers to the knowledge structure used by entrepreneurs in the evaluation and decision making of entrepreneurial processes, such as opportunity identification, enterprise creation and growth [32]. Mitchell (1994) reported that successful entrepreneurs rely on three cognitive resources, namely, identifying entrepreneurial opportunities, acquiring entrepreneurial resources and mining entrepreneurial models [33]. Accordingly, the entrepreneurial cognition can be divided into three dimensions, namely entrepreneurial willingness, resources, and ability. Entrepreneurial cognition influences the type of cognitive model entrepreneurs adopt in integrating the scattered information and necessary resources and help them start a business. Thus, the cognitive model of entrepreneurs is the external manifestation of this knowledge structure. Individuals' cognitive model refers to their different preferences and habits in organizing and processing information, including two basic models, namely, intuitive and analytical models [34]. Entrepreneurs who adopt intuitive cognition tend handle unfamiliar or unstructured information and identify clues or signals, generally not occupying or occupying less psychological resources. Therefore, this cognitive model is applicable in uncertain and dynamic environments (e.g., entrepreneurial activities). Conversely, the analytical cognitive model refers to individuals who pay attention to using rationality and rules to evaluate external information and make decisions, which takes up more psychological resources.

With the continuous accumulation of entrepreneurial experience of entrepreneurs, their entrepreneurial decision making is alternately affected by analytical cognitive model and intuitive cognitive model. In addition, the dominant cognitive model can control the behavior of entrepreneurs in decision making [35,36]. Kickul et al. (2009) found through empirical research that intuitive cognitive model enables entrepreneurs to gain confidence in the identification and evaluation of opportunities [37]. In other words, the entrepreneurs can quickly and accurately explore entrepreneurial opportunities and train their intuitive ability to entrepreneurial opportunities. Although intuitive cognitive model can help entrepreneurs immediately determine simplified strategies to reduce uncertainty, it may also cause cognitive biases, such as over optimism or over pessimism [38]. In comparison to the intuitive cognitive model, the analytical cognitive model is a cognitive process when faced with complex tasks and lack of typicality [39]. If the intuitive cognitive model is an immediate and direct process, then the analytical cognitive model requires selective transformation, extensive research, and refinement of existing information.

In the past, research on entrepreneurial cognition mainly focused on the results of static cognitive activities, such as the influence of cognition on entrepreneurial willingness and entrepreneurial efficacy $[32,40]$ and then on entrepreneurial performance. That is, entrepreneurial cognition can explain the reasons of entrepreneurial success from the cognitive level. However, few studies on the influence of positive emotion on cognitive process are available. Although the intuitive cognitive model combines uncertainty and allows entrepreneurs to deviate from the linear path, which is different from the hypothesis of rational choice model in traditional economics, it ignores the effects of other motivations on entrepreneurs and still cannot explain why entrepreneurs and the complex cognitive process of entrepreneurs' continuous entrepreneurship. Therefore, a comprehensive theoretical framework is further needed. 


\subsection{Entrepreneurial Affect and Positive Psychology}

Entrepreneurial affect refers to the emotions, moods, or feelings of entrepreneurs that accompany the entire process of entrepreneurship [41]. As an important psychological feature of entrepreneurs, it plays an important role in optimizing entrepreneurial cognitive ability, inducing entrepreneurial behavior and then affecting entrepreneurial performance [12,42,43]. Entrepreneurial emotion has two dimensions, namely, valence and arousal [44]. Valence level, also known as pleasure, changes from positive to negative emotions. Arousal level is the intensity of emotion, which changes from high to low arousal.

Scholars have emphasized the role of entrepreneurial emotion in entrepreneurial cognition, which influences information processing strategies and then entrepreneurial opportunity recognition and assessment [11,45], information storage and extraction [46] and knowledge integration. Baron (2008) also proposed two mechanisms of the influence of emotion on cognition. The first mechanism is the priming effect, in which, given emotion as a filter of memory information, different emotion types will stimulate different memories. The second mechanism is the heuristic cue, that is, emotion as the basis of judgment and decision making. When individuals experience positive emotional state, they will make a positive judgment and evaluation of the external factors. In a highly uncertain and dynamic environment, positive emotions can enable entrepreneurs to make decisions quickly and effectively, promote entrepreneurs to cope with setbacks and pressures [11] and affect the response of entrepreneurs after failure. Entrepreneurial failure can make entrepreneurs produce sad emotions; thus, some scholars have studied how entrepreneurs balance economic and emotional costs with positive emotions [47]. From the perspective of organizational innovation, Baron and Tang (2011) found that positive emotions can expand the cognitive scope of individuals and enhance the creativity of entrepreneurs [42]. On the basis of dynamics, complexity and uncertainty of the entrepreneurial process, the emotional state in decision making may affect the judgment and results of entrepreneurs differently, and emotions may play an important role in it [48].

In view of the relationship between entrepreneurial emotion and entrepreneurs' cognition and behavior, this study attempts to explore with the perspective of positive psychology. Positive psychology is a science about 'positive subjective experience, positive personal characteristics and positive system'. It discusses the influence of positive experience on individual cognition and behavior [49] and forms two research paradigms, namely, Hedonic and Eudaimonic well-being. The former believes that happiness is the ultimate goal of human behavior and the real essence of behavioral motivation, and people make rational choices to maximise their enjoyment; the latter is the happiness based on the realisation of individual self-worth [24]. Hahn et al. (2012) attempted to study the influence of two types of well-being on the individual initiative of entrepreneurs according to the broaden and build theory. They also predicted that Hedonic well-being can improve the initiative of entrepreneurs by establishing psychological resources. Moreover, the more active entrepreneurs are, the more they can to adhere to entrepreneurial activities [50]. Evidently, as a behavioral goal and motivation, happiness has been paid attention, but the research on it in the field of entrepreneurship is limited, especially in the aspect of explaining entrepreneurial motivation. Therefore, this study attempts to capture happiness in entrepreneurship to clarify the behavior in the process of entrepreneurship.

To sum up, research on entrepreneurial emotion is based on 'emotion influencing individual cognition and behavior'. In the field of entrepreneurship, although it gradually involves research on the emotion and subjective feelings of entrepreneurs in the process (e.g., Dijkhuizen et al. (2016)), considering that positive emotion may affect enterprise level variables (e.g., entrepreneurial performance) [12] while the mechanism is unexplained. Moreover, there is few discussion on positive emotion to entrepreneurs' adherence to entrepreneurial behavior; most previous studies only focused on the emotion of satisfaction [48]. Emotion influences the entrepreneurial process through cognition. Entrepreneurs experience different emotional fluctuations in various stages of entrepreneurship [51]. However, in this process, which entrepreneurs will adhere to and which entrepreneurs are more inclined to give up? Does personal emotion contribute to the promotion of entrepreneurship? 
These questions remain to be inadequately answered. Therefore, this study should combine the function of entrepreneurial emotion to analyse entrepreneurial cognition and behavior. Moreover, the emotional changes of entrepreneurs in the process of entrepreneurship should be elucidated, and how entrepreneurs attempt to adhere to entrepreneurship should be explored.

\section{Research Design}

\subsection{Methods}

This study aims at exploring the driving factors of entrepreneurs' continuous efforts under uncertain conditions to solve the problem of 'why' as well as, (A mechanism of driving key elements of entrepreneurship and the influence of emotion on entrepreneurial cognition and behavior in the process of entrepreneurship) 'how. The questions that should be explored are highly dynamic and complex. In addition, exploring the entrepreneurial process from an emotional perspective is still at its infancy stage. Case studies are most suitable for answering such questions [52]. Through a case study, the present work deeply analyses the causal logic of the phenomenon and reveals the internal mechanism of entrepreneurs' positive psychology that influences entrepreneurial behavior. Multi-case studies allow cross case mode exploration, which helps establish general items and tells how those specific conditions are related to one another [53]. Therefore, this work adopts a multi-case study method to help develop new convincing theories. According to grounded theory, this study codes and analyses the case data and construct a positive emotion model in the entrepreneurial process via inductive analysis.

\subsection{Samples}

Theoretical sampling is the basic principle of grounded theory. It refers to the need to extract samples that can provide the maximum amount of information for research problems according to the purpose and the theoretical guidance of research design. This study uses this method to select suitable samples. To overcome the biases of entrepreneurs' recollection of past behaviors caused by interviews or questionnaires, this study uses entrepreneurs' Weibo and blog as the main sample selection reference source to increase the authenticity and traceability of data. Firstly, to cover a complete entrepreneurial process, we limit the sample selection to $2-5$ years of Weibo or blog recording time to ensure sufficient entrepreneurial time span. Secondly, entrepreneurs who fully record their behavior and emotional expression on Weibo or blog are selected, whereas those who primarily promote companies and their products are excluded. In consideration of the influence of entrepreneurial experience on entrepreneurial behavior, the sample should include first-time and continuous entrepreneurs. Finally, we select six typical cases from different industries with various scales (Table 1).

Table 1. Sample introduction.

\begin{tabular}{|c|c|c|c|c|}
\hline Entrepreneurs & Case Introduction & Weibo Data & Other Data Sources & Remarks \\
\hline Du Mengjie & $\begin{array}{l}\text { Dreamore website, } \\
\text { crowdfunding industry }\end{array}$ & $\begin{array}{c}\text { February } \\
\text { 2011-March } 2015 \\
\text { (4258 items) }\end{array}$ & $\begin{array}{l}\text { Sina blog, enterprise } \\
\text { Weibo, video and } \\
\text { news interviews }\end{array}$ & $\begin{array}{c}\text { First venture; } \\
\text { entrepreneurship of college } \\
\text { students; unprofitable two } \\
\text { years before start-up }\end{array}$ \\
\hline Wang Kuncheng & Kaiheba, experience gifts & $\begin{array}{c}\text { February } \\
\text { 2010-March } 2015 \\
\text { (565 items) }\end{array}$ & $\begin{array}{l}\text { Sina blog, } \\
\text { news interview }\end{array}$ & $\begin{array}{l}\text { First venture; start a business } \\
\text { after studying abroad }\end{array}$ \\
\hline Xu Xiaohui & $\begin{array}{l}\text { CRUCCO, clothing } \\
\text { e-commerce }\end{array}$ & $\begin{array}{c}\text { August } \\
\text { 2010-March 2015 } \\
\text { (8000 items) }\end{array}$ & $\begin{array}{l}\text { Sina blog, video and } \\
\text { news interviews, } \\
\text { journal articles }\end{array}$ & $\begin{array}{l}\text { Resign from Vanke; first } \\
\text { venture; finally acquired }\end{array}$ \\
\hline Guo Ziwei & $\begin{array}{l}\text { Chanyouji, mobile } \\
\text { tourism industry }\end{array}$ & $\begin{array}{c}\text { August } \\
\text { 2009-March } 2015 \\
\text { (7440 items) }\end{array}$ & $\begin{array}{l}\text { Sina blog, } \\
\text { news interview }\end{array}$ & $\begin{array}{l}\text { Resign from NetEase; } \\
\text { first venture }\end{array}$ \\
\hline Zhang Liaoyuan & $\begin{array}{l}\text { Three Squirrels, Internet } \\
\text { food company }\end{array}$ & $\begin{array}{c}\text { February } \\
\text { 2011-March } 2015 \\
\text { (4940 items) }\end{array}$ & $\begin{array}{l}\text { Sina blog, video and } \\
\text { news interviews }\end{array}$ & $\begin{array}{l}\text { Serial entrepreneur; work with } \\
\text { others to successfully create an } \\
\text { e-commerce and leave }\end{array}$ \\
\hline Chaike & $\begin{array}{l}\text { Yoloho, healthcare } \\
\text { industry }\end{array}$ & $\begin{array}{c}\text { February } \\
\text { 2011-March } 2015 \\
\text { (2072 items) }\end{array}$ & $\begin{array}{l}\text { Sina blog, video and } \\
\text { news interviews }\end{array}$ & $\begin{array}{l}\text { Serial entrepreneur; eight } \\
\text { entrepreneurial failures }\end{array}$ \\
\hline
\end{tabular}




\subsection{Data Collection and Analysis Strategy}

To ensure the reliability of data, this study adopts the triangulation method [54] and selects various channels to obtain information. In this study, entrepreneurs' Weibo and blog are used as the main data sources to collect their entrepreneurial behaviors and emotional experience expressions in the natural environment. Microblog and blog data are selected for three reasons. Firstly, the data content can reflect the emotion and cognition of the research object at that time and record the entrepreneurial events and behaviors in real time. Secondly, the data source records the time, with time continuity, and can reproduce the entrepreneurial process. Finally, the data have a short time interval, which can effectively avoid recall bias and reverse causality. Other auxiliary data sources include relevant interviews, public speeches and journal articles of entrepreneurs, as well as relevant video materials from Tencent video, Youku and other domestic mainstream video websites. These sources can aid in understanding and mastering comprehensive information. The sample includes four first-time entrepreneurs and two continuous entrepreneurs. The total items of Weibo collected by the six entrepreneurs is 27,275 , and the collection of blog data is 56,000 words. Other data sources have a total of 73,000 words.

\section{Data Analysis}

We select six samples under the above sample selection criteria, and we analyse the documents through NVivo software. NVivo can collect a substantial information related to a subject and has strong coding function, which enables researchers to quickly capture the information points contained in the material source. We select Du Mengjie's case as the starting point of analysis, then the remaining four entrepreneurial cases are coded and analysed individually. Finally, the coding analysis of Chaike's case, who has eight entrepreneurial failure experiences, is completed. We hope to gradually revise and develop the research results through this process to achieve theoretical saturation.

\subsection{Open Coding}

Open coding refers to the process of analyzing samples on a word-by-word basis, abstracting data into concepts and categories and recombining them. Its main purpose is to analyse and converge phenomena and problems. This study follows the coding idea of exploratory research and performs open coding. This study is performed with NVivo software. Firstly, the Weibo and blog of each entrepreneur is downloaded, as well as relevant interview reports, video reports and other media materials. The materials of each entrepreneur are imported, and coding is started for the first time. The first coding is free coding, which determines the main concepts and events (e.g., angry, happy and sad), the changes of entrepreneurs' main behavior and motivation and the key activities of the entrepreneurial process. After coding the first case as a template, the second case is coded to modify and supplement the new nodes and then the other case codes. This case is further modified and supplemented to improve the external validity of this study. Finally, 133 free nodes are obtained.

\subsection{Spindle Coding}

After the open coding, the nodes and categories are basically independent. Thus, the relationship between them should be further analyzed through spindle coding. According to Russell's (1980) [44], emotional circle model, this study analyses the emotion of entrepreneurial process with language classifies and codes the events and activities of entrepreneurial process. Through the second coding node classification, 23 types of genera are obtained, including 15 types of behavior event, two major categories of positive and negative emotions, three types of key resources in the process of entrepreneurship (i.e., entrepreneurial willingness, ability and resources), and three types of cognitive structure (i.e., entrepreneurial knowledge, creative cognition and entrepreneurial alertness). In the emotional aspect, nine main emotions are encoded, including four positive emotions (i.e., excitement, happiness, satisfaction, and relaxation) and five negative emotions (i.e., depression, anger, boredom, fatigue, and fear). 


\subsection{Selective Coding}

Selective coding grasps a better understanding of the specific meaning of the basic framework by selecting the core categories and combining the relationship between other categories [55]. This coding focuses on the above nine emotions and is based on Russell's (1980) circular model to modify and draw the circular model of emotions in this case. As shown in Figure 1, the $X$-axis is the valence level, whereas the $Y$-axis is the arousal degree. At the same time, this study focuses on the classification of key activities in the process of entrepreneurship, such as the coding of entrepreneurial willingness and ability and, as well as motivation-related events and behaviors. Through case coding, this study finds a similar emotion behavior model and uses the last case for validation. Finally, this model is combined with the existing theory to analyze the motivation of entrepreneurs' continuous efforts. An in-depth case study is used to explore the mechanism of motivation.

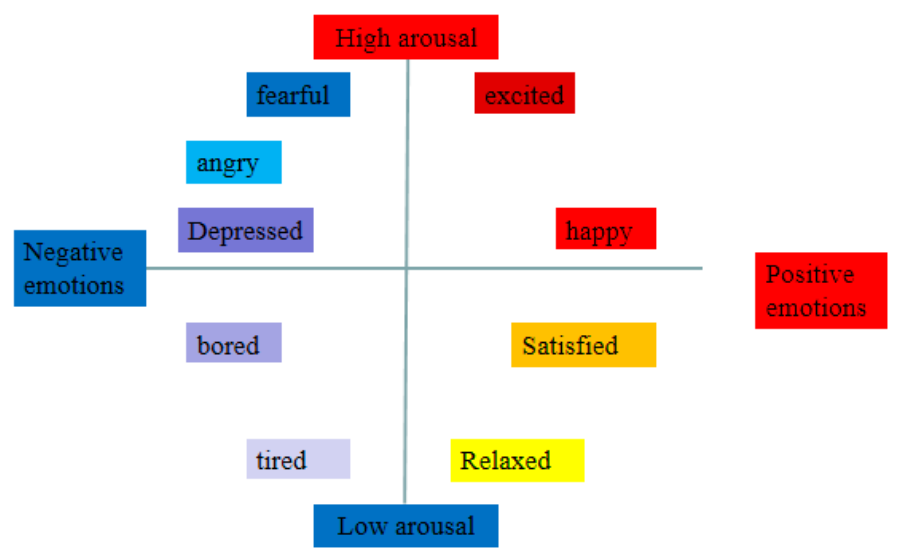

Figure 1. Circular model of emotion (modified; Russell, 1980).

This study also analyses the semantic of emotion dictionary to improve the reliability and validity of coding. In the aspect of emotional semantic analysis, developed countries have relatively mature emotional dictionaries, such as the Dictionary of Influence in Language, WordNet and Wiktionary; however, these dictionaries are based on English semantics and are not suitable for the analysis of this study. At present, the National Taiwan University Semantic Dictionary (NTUSD), developed by Taiwan University, and HowNet, developed by Dong Zhendong, are available. On the basis of entrepreneurs' emotion in this study, words that pertain to positive and negative emotions and evaluation words in the above two emotion dictionaries are selected and integrated, and repeated words are eliminated to form the emotion dictionary of this study (Table 2).

Table 2. Word set for emotional analysis.

\begin{tabular}{ccc}
\hline Emotion Dictionary & Term Set Name & Number of Words \\
\hline \multirow{2}{*}{ NTUSD } & Positive emotional words & 2810 \\
& Negative emotional words & 8276 \\
& Positive emotional words & 755 \\
\multirow{2}{*}{ HowNet } & Negative emotional words & 1218 \\
& Positive evaluation words & 3360 \\
& Negative evaluation words & 3082 \\
\multirow{2}{*}{ Emotional dictionary of this study } & Positive emotional words & 6176 \\
& Negative emotional words & 10,280 \\
\hline
\end{tabular}

\section{Case Analysis and Discovery}

This study focuses on the entrepreneurial emotion in the context of uncertain entrepreneurial environment. Thus, it mainly focuses on the start-up stage, which is about the process of entrepreneurial preparation and establishment and product/service launch. On the basis of the 
analysis, the entrepreneurial process is divided into pre-launch, launch and post-launch stages [56]. Through the above analysis, we find that entrepreneurial emotion influences entrepreneurial cognition by changing the cognitive structure and process of entrepreneurs and affects entrepreneurial activities (i.e., formation of entrepreneurial willingness, acquisition of entrepreneurial resources and development of entrepreneurial ability) and ultimately leads to differentiated entrepreneurial results. Therefore, this study analyses the aforementioned process from the perspective of entrepreneurial process and combines the main viewpoints of entrepreneurial cognitive theory and positive psychology theory. It also proposes relevant propositions. Finally, we construct a model of positive emotion in the process of entrepreneurship.

\subsection{Entrepreneurial Emotional Characteristics in Different Stages of Entrepreneurial Development}

\subsubsection{Pre-launch Stage}

The pre-launch stage refers to the period from the generation of entrepreneurial ideas to the launch of products/services. At this stage, entrepreneurs devote their entrepreneurial passion to the preparation of products/services and the establishment of entrepreneurial teams. In the process, they are full of unknowns and visions, which make their emotions complex and changeable. According to the data analysis, the statistical summary of reference points of emotion node coding before the start-up of entrepreneurship is shown in Table 3, where the meaning of 'source number' is the number of channels of data sources and the 'reference points' refers to how many related quotes of emotions are found from these data sources(the same below). At this stage, first-time and continuous entrepreneurs have highly aroused positive emotions, such as excitement (reference point 22) and happiness (reference point 15). Meanwhile, given high uncertainty of the environment, entrepreneurs cannot control all factors (e.g., market environment, customers, and competitors) and cannot predict future results. Therefore, at this stage, entrepreneurs also have highly aroused negative emotions, such as fear (reference point 10) and depression (reference point 8).

Table 3. Emotional coding at the pre-launch stage of entrepreneurship.

\begin{tabular}{|c|c|c|c|c|}
\hline \multicolumn{2}{|c|}{ Emotional Categories } & $\begin{array}{l}\text { Source } \\
\text { Number }\end{array}$ & $\begin{array}{l}\text { Reference } \\
\text { Points }\end{array}$ & Typical Quotes \\
\hline \multirow{2}{*}{ Positive emotion } & Нарру & 12 & 15 & $\begin{array}{c}\text { 'We are experiencing the passion and happy time of } \\
\text { our initial business'. }\end{array}$ \\
\hline & Excited & 12 & 22 & $\begin{array}{l}\text { 'It's also exciting for me to decide to start a business'. } \\
\text { 'I suddenly felt very scared. I was afraid that }\end{array}$ \\
\hline \multirow{4}{*}{ Negative emotion } & Fearful & 6 & 10 & $\begin{array}{l}\text { entrepreneurship would develop too fast and grow } \\
\text { like weeds without rules and bottom lines'. }\end{array}$ \\
\hline & Depressed & 7 & 8 & $\begin{array}{l}\text { 'It's a bit depressed. There's very little to borrow } \\
\text { around. There's really not much to do'. }\end{array}$ \\
\hline & Anxious & 5 & 6 & $\begin{array}{l}\text { 'There are too many unknowns on the road of } \\
\text { entrepreneurship. These three days have been spent } \\
\text { in anxiety and helpless'. }\end{array}$ \\
\hline & Tired & 4 & 5 & $\begin{array}{l}\text { 'If you choose to start a business, you have to be } \\
\text { used to staying up all night. No one knows how } \\
\text { hard and tired you are'. }\end{array}$ \\
\hline
\end{tabular}

The encoded data indicate that the most frequent positive emotion at this stage is 'excitement'. The emotion excitement has two main reasons, namely, social support and new experiences. On the one hand, obtaining support and recognition at this stage helps entrepreneurs identify their ideas and perspectives. The support of family members gives them courage, and the encouragement of friends can also firm their original intention to start a business. Du Mengie said, 'The first step to start a business is to persuade people around you to support you'. On the other hand, in this process, entrepreneurs constantly experience new things and meet new friends. They are excited and happy to learn new knowledge and rapidly grow. Guo Ziwei wrote in his Weibo, 'It's very happy to do product planning and design, to select furniture and appliances by hand, to build team culture according to his own preferences and to be busy and happy'. 
Entrepreneurship remains in the exploratory stage; thus, entrepreneurs often think about the significance and original intention of entrepreneurship. Although different entrepreneurs with different entrepreneurial motives, they all realize that they are enjoying different experiences brought by entrepreneurship, which makes them happy and satisfied in the process. As Xu Xiaohui wrote in his Weibo, "The driving force for me to leave a big company and start a business is not to be famous or rich, but to make products with a group of people I like and in the way I like, that's all'.

Although this stage overflows with excitement and happiness, various negative emotions. Amongst them, fear and depression are the main highly aroused negative emotions. Fear comes mainly from uncertainty. Before the launch of products/services, entrepreneurs often question whether the chosen entrepreneurial path is right and cannot predict whether and when the existing investment will be rewarded. First-time entrepreneur Du Mengjie said, 'At the beginning of entrepreneurship, I feel confused about the future. I don't know how to do it, since I have no experience, no resources, no channels, and no money'. The main source of depression is the lack of support and criticism. Firstly, most entrepreneurs are limited by capital, scale and resources at the initial stage, which makes recruiting excellent employees challenging. Secondly, given the uncertainty of the entrepreneurial stage, entrepreneurs consult with friends and relevant people to gather feedback and negotiate with potential investors. Some entrepreneurs have gained support, encouragement and positive feedback. However, the majority of entrepreneurs have been questioned and criticized, which is undoubtedly a heavy blow to entrepreneurs who have only started to engage in entrepreneurial activities.

The existing research posits that positive and negative emotions have opposite effects on cognition or behavior [11]. However, this study finds that at this stage, entrepreneurs can integrate the effects of these emotions, and highly awakened positive and negative states can increase their future efforts and investment [57]. When entrepreneurs are under negative emotions, such as fear and depression, entrepreneurs who can persist actively seek recognition and affirmation. In other words, entrepreneurs strive to overcome the influence of negative emotions by gaining positive recognition from society. Entrepreneurs who can persevere believe that this is a setback that entrepreneurs will experience and is a process of honing and learning experience for themselves. As Wang Kuncheng said, 'All new ideas and ways will encounter countless negations, some of which are indeed directly hung up, but bring many valuable experiences'. Accordingly, we propose the following.

Proposition 1a. In the pre-launch stage, entrepreneurs experience positive and negative emotions that are highly aroused. Entrepreneurs overcome negative emotions by gathering positive feedback to gain positive emotions.

\subsubsection{Launch Stage}

Table 4 summarizes the categories and reference points of positive and negative emotions in the launch stage. At this stage, the emotional state of entrepreneurs has a high arousal of positive emotions, most of which are excited and satisfied. Du Mengjie said, 'When the product officially went online and entered the countdown of ten days, I found that I was getting more and more excited.' At the same time, the launch of the product also marks the phased achievements of entrepreneurs. In this process, they thank their families, friends and team members for their support. As Xu Xiaohui mentioned, 'The initial stage of entrepreneurship is the most difficult period. It's true friends who are willing to help you when you start. I will remember those warm assistance and thank them at some time in the future'. In addition, entrepreneurs are happy with product launch and eager to know feedback from others. After the product is officially launched, it can test their past efforts and clear assessment achievements. Therefore, most of the emotions described by entrepreneurs are positive and show a high level of arousal. As Xu Xiaohui wrote, 'We are coming and waiting for your review'. 
Table 4. Emotional coding at the launch stage of entrepreneurship.

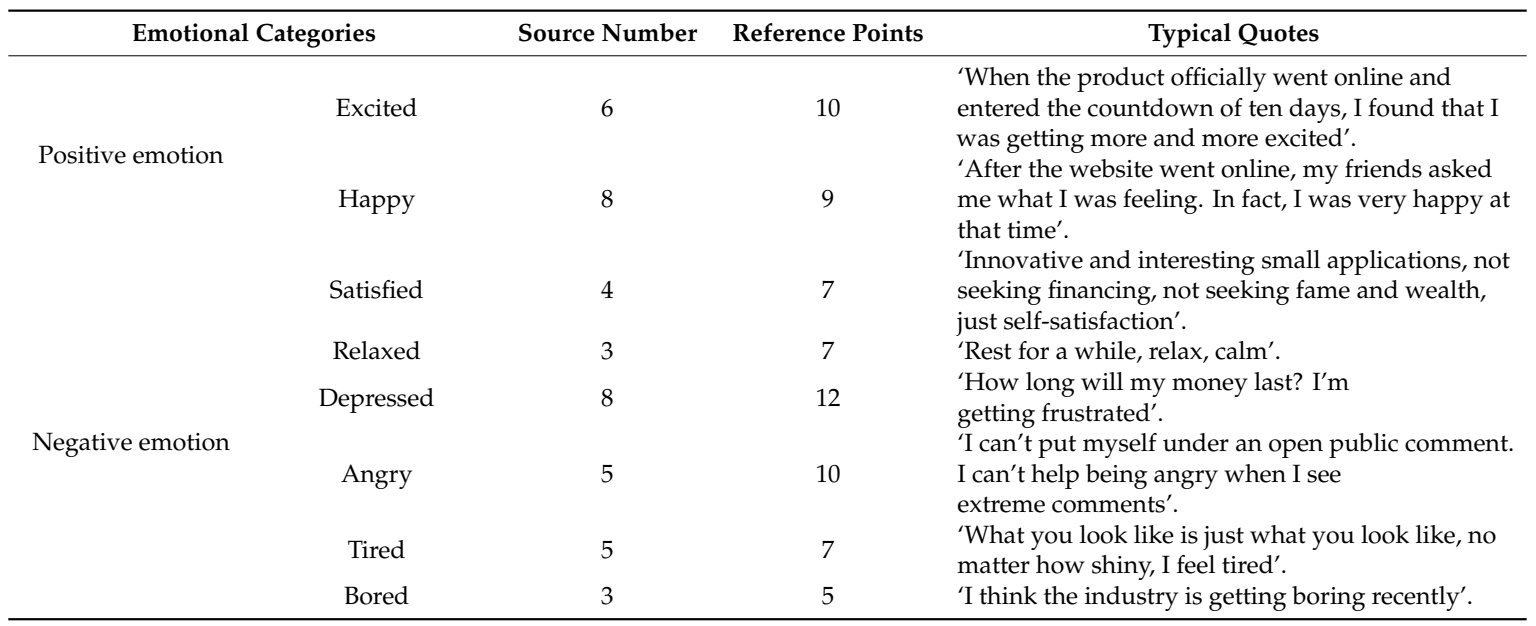

However, when the product is successfully launched, entrepreneurs must also perform many trivial and time-consuming management tasks, which causes entrepreneurs to generate low level of arousal of negative emotions, such as depression and fatigue, thereby reducing their entrepreneurial motivation. As Guo Ziwei mentioned, 'Entrepreneurs have to bear too many policies and taxes. This week, the bureau of accounting, auditing, industry and commerce, quality and technical supervision will be completed'. Repetitive tasks uninspired and exhausted him. In addition, they will face negative feedback (e.g., direct criticism) after the product goes online. Guo Ziwei stated that 'When we first accept the market inspection after the product is launched, our mood starts to get worse, and most of our products will encounter obvious problems; then we need to find ways to solve all kinds of new problems, and our mood will gradually get lower and lower'. Therefore, at this stage, entrepreneurs are overwhelmed with self-doubt and confusion and in a low arousal of negative emotions, which may lead to their withdrawal from entrepreneurship.

Entrepreneurs should have practical achievements or change their attitudes to escape from the low-arousal negative emotional state. When entrepreneurs feel depressed or bored, they strive to eliminate this negative emotional state. Entrepreneurs who have been in the low-arousal negative emotional state for a long period search for reasons for them to persist. As mentioned by Du Mengjie, 'I still couldn't think clearly about our product, Zhuimeng.com, and took a lot of detours. The whole thing was very painful... We still have to go back to the beginning, why did we start a business at the beginning'. As a result, negative emotions encourage entrepreneurs to engage in behaviors that bring positive emotions, such as thinking about new business ideas or seeking affirmation, or copying behaviors that excite them in the past, which can help them eliminate self-doubt. Therefore, this study proposes the following.

Proposition 1b. At the launch stage, entrepreneurs have high-arousal positive emotions and low-arousal negative emotions. To eliminate the reduction of entrepreneurial motivation caused by negative emotions, they recall the positive emotions in the process of entrepreneurship, regain the original intention of entrepreneurship and then insist on entrepreneurship.

\subsubsection{Post-launch Stage}

At this stage, the 'personal kingdom' established by entrepreneurs is becoming increasingly stable and mature, the customer base of enterprises is increasing and the entrepreneurial network is gradually expanding. This phenomenon increases the predictability of entrepreneurial path, and entrepreneurs are more comfortable with a series of problems in the process of entrepreneurship. The case analysis indicates that entrepreneurs at this stage experience a relatively low degree of arousal emotional state. 
Entrepreneurs at this stage experience positive emotions, such as excitement and happiness, mainly due to the addition of new product functions or the introduction of new products, that is, considering enterprise growth. Du Mengjie said, 'At this stage, I need to think more systematically and logically about what role I should play in the future, rather than relying on my own interests.' At this stage, the product launch can acquire consumer feedback fast. When the product is approved, it will generate positive emotions, whereas when the product fails to launch, it will generate negative emotions (e.g., depression). The negative emotions experienced by entrepreneurs also come from tedious management tasks. Chaike said, 'With the growth of entrepreneurial teams, people will be tired, and institutionalized management must gradually replace humanized management. No team can keep excited for a long time, so if the system is not kept up with in time, humanized management will lead to low work efficiency.' Thus, at this stage, entrepreneurs frequently feel the positive and negative emotional cycle; however, the degree of arousal is relatively low compared with the previous stage. Therefore, the following proposition is proposed.

Proposition 1c. In the post-launch stage, entrepreneurs repeatedly experience the positive and negative emotional cycle of low degree arousal. Entrepreneurs go through the stage of self-doubt and begin to think about the growth of enterprises.

To sum up, entrepreneurs have been attempting to gain positive emotions by reconstructing the entrepreneurial process. In other words, when corporate goals have not been achieved and personal goals or achievements are difficult to evaluate, entrepreneurs overcome negative emotions and stick to entrepreneurship through behavioral strategies. Through data analysis, this study summarizes the behaviors that can promote entrepreneurs to generate positive emotions and summarizes the results of emotion and behavior strategies obtained from the analysis, as shown in Table 5. On the basis of data coding, the events related to the emotional state in the entire entrepreneurial stage are summarized in Table 6.

On the basis of emotional lexicon, this study analyses the emotional trend of entrepreneurial stage. We find that entrepreneurial emotion is a circular process. Figure 2 shows the ratio of positive and negative emotional words in the process of entrepreneurship. The $x$-axis represents the time of entrepreneurship, whereas the $y$-axis represents the ratio of emotional words to total words.

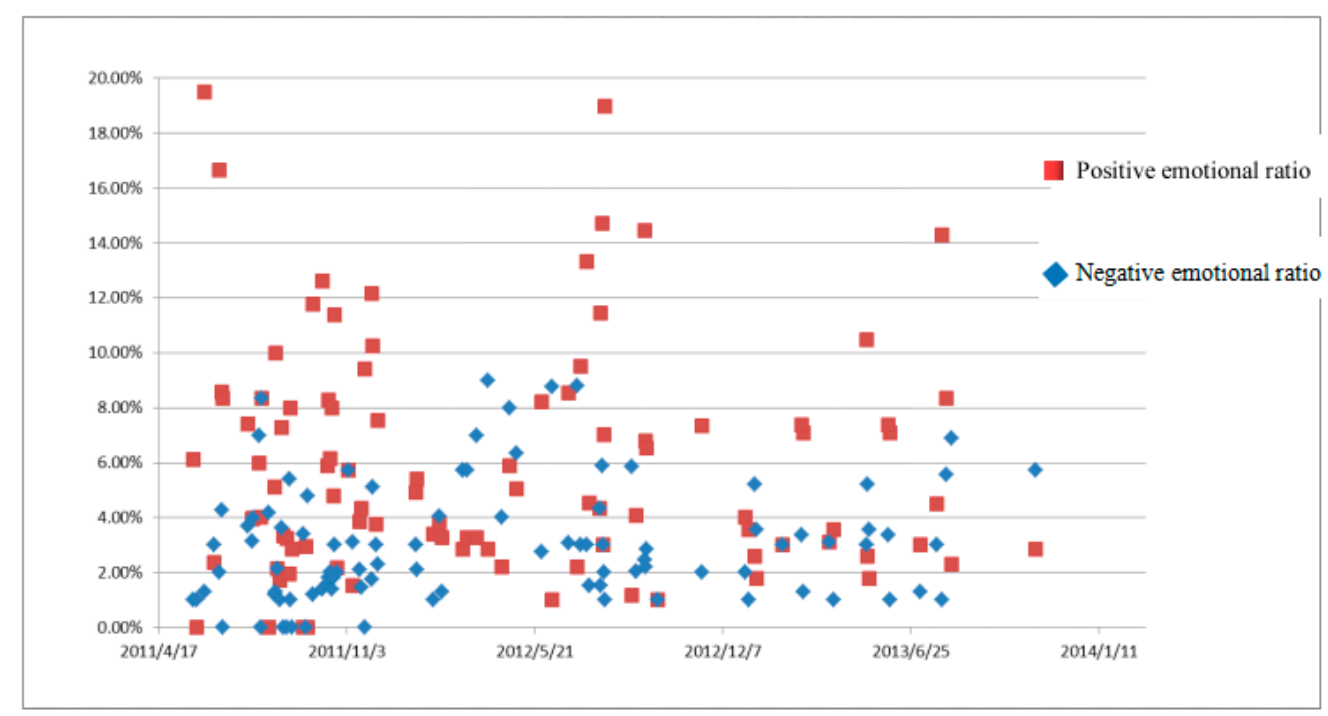

Figure 2. Analysis of emotion trend based on emotion dictionary. 
Table 5. Goal, emotion and behavior strategy in the entrepreneurial stage.

\begin{tabular}{|c|c|c|c|}
\hline Entrepreneurial Stage & Goal & Emotion & $\begin{array}{l}\text { Behavioral Strategies for Acquiring } \\
\text { Positive Emotions }\end{array}$ \\
\hline Pre-launch stage & $\begin{array}{l}\text { (1) Establish entrepreneurial team } \\
\text { (2) Focus on short-term goals; prepare to } \\
\text { launch products and services }\end{array}$ & $\begin{array}{l}\text { Positive emotions: excitement and joy } \\
\text { (experience new things and get support) } \\
\text { Negative emotions: fear and depression } \\
\text { (environmental uncertainty, lack of } \\
\text { resources, and support and criticism) }\end{array}$ & $\begin{array}{l}\text { (1) Acquire support and recognition from family, } \\
\text { friends and other relevant personnel } \\
\text { (2) Selective feedback } \\
\text { (3) Use this stage as a process to accumulate experience }\end{array}$ \\
\hline Launch stage & $\begin{array}{l}\text { (1) Launch new products and services } \\
\text { (2) Review and reflect on the } \\
\text { entrepreneurial process }\end{array}$ & $\begin{array}{l}\text { Positive emotions: excitement and } \\
\text { happiness (positive feedback after } \\
\text { product launch; success) } \\
\text { Negative emotions: depression, } \\
\text { confusion (negative feedback or failure } \\
\text { after product launch), boredom and } \\
\text { tiredness (repeated tasks) }\end{array}$ & $\begin{array}{l}\text { (1) Review and reflect on the entrepreneurial process } \\
\text { and engage in the past to bring positive experience } \\
\text { (2) Redefining the cause of entrepreneurship and taking } \\
\text { the process of entrepreneurship as a process of learning } \\
\text { and growth }\end{array}$ \\
\hline Post-launch stage & $\begin{array}{l}\text { (1) Optimise existing product services or } \\
\text { launch new products } \\
\text { (2) Consider enterprise growth }\end{array}$ & $\begin{array}{l}\text { More frequent feelings of positive } \\
\text { (success) and negative (failure) }\end{array}$ & $\begin{array}{l}\text { (1) Engage in past successes } \\
\text { (2) Launch new products and services } \\
\text { (3) Seeking broader support and recognition }\end{array}$ \\
\hline
\end{tabular}

Table 6. Events and emotions in entrepreneurial process.

\begin{tabular}{|c|c|c|c|}
\hline Events/Behaviors/Situations & Emotional State & Entrepreneurial Stage & Events/Behaviors/Situations of Emotional Change \\
\hline Thinking about business ideas & Positive emotion, high arousal (excited and happy) & Pre-launch and post-launch stages & To receive criticism without support (depressed and angry) \\
\hline Acquire support and recognition & Positive emotion, high arousal (excited, happy) & Entire stage of entrepreneurship & \\
\hline New product launch & Positive emotion, high arousal (excited, happy) & Launch and post-launch stages & Market saturation and product failure (sad and depressed) \\
\hline Plan long-term goals & Positive emotion, high arousal (excited) & Pre-launch and post-launch stage & Lack of resources and support (depressed and sad) \\
\hline Focus on short-term goals & Positive emotion, moderate arousal (satisfied) & Entire stage of entrepreneurship & Heavy and trivial tasks (depressed and bored) \\
\hline Rest after being busy & Positive emotions, low arousal (relaxed) & Launch and post-launch stage & New business ideas and products (excited and happy) \\
\hline Meet new friends & Positive and negative emotions, high arousal (happy and fearful) & Entire stage of entrepreneurship & \\
\hline Redefining business ideas & Positive and negative emotions, high arousal (excited and distressed) & Entire stage of entrepreneurship & To receive criticism without support (depressed and angry) \\
\hline Review past experience & $\begin{array}{l}\text { Positive emotions, high arousal (happy); and negative emotions, low } \\
\text { arousal (depressed) }\end{array}$ & Entire stage of entrepreneurship & To succeed after negative emotions (happy) \\
\hline New product launch failure & Negative emotions, high arousal (sad and ashamed) & Launch and post-launch stage & $\begin{array}{l}\text { Analyze the causes of failure, regard failure as learning } \\
\text { experience and gain growth and support } \\
\text { (happy and satisfied) }\end{array}$ \\
\hline $\begin{array}{l}\text { Uncertain environment and } \\
\text { future results }\end{array}$ & Negative emotions, highly aroused (fearful) & Pre-launch stage & Obtain support and recognition (happy) \\
\hline Obtaining criticism and questions & Negative emotions, highly aroused (depressed and angry) & Entire stage of entrepreneurship & $\begin{array}{l}\text { Analyze the cause of the incident and listen to it } \\
\text { selectively (satisfied) }\end{array}$ \\
\hline Economic insecurity & Negative emotions, low to moderate arousal (depression) & Entire stage of entrepreneurship & $\begin{array}{c}\text { Obtain support and reanalyze entrepreneurial motivations } \\
\text { (relaxed and satisfied) }\end{array}$ \\
\hline Management/daily tasks & Negative emotions, low arousal (tired) & Launch post-launch stages & $\begin{array}{c}\text { Review the past, see it as a growth process and re launch } \\
\text { the product (satisfied and excited) }\end{array}$ \\
\hline
\end{tabular}




\subsection{Entrepreneurial Motivation Driven by Emotion}

On the basis of the dynamic nature of entrepreneurial process, what drives entrepreneurs to insist on entrepreneurship? By analyzing the entrepreneurs' emotion model and behavior strategy, this study finds that the entrepreneur obtains positive emotion through entrepreneurial behavior. The entrepreneurial process becomes the source of entrepreneurial motivation, and the acquisition of happiness or self-realization in the process may become the pursuit of entrepreneurs [58]. When no external reward exists, the interest in the activity and the spontaneous efforts to realize the self are the positive and advanced motivations concerned by positive psychology $[59,60]$. When entrepreneurs achieve their psychological needs through certain behaviors that lead to positive emotions, they will invest in similar behaviors to maximize their level of happiness. Therefore, in the process of entrepreneurship, numerous behaviors seem irrational and deviate from the long-term goal. Nevertheless, entrepreneurs should acquire positive emotions to adhere to entrepreneurship. This study reveals how entrepreneurs establish sustained efforts from an emotional perspective, which will be described in turn on the basis of the entrepreneurial process.

In the pre-launch stage, entrepreneurs have highly aroused positive and negative emotions. At this stage, the goal of entrepreneurs is clear, and most of their time and energy are spent in preparation for entrepreneurship. In this process, entrepreneurs constantly experience new things and obtain recognition, bringing highly aroused positive emotions. Entrepreneurs are faced with a high degree of arousal of negative emotions caused by uncertain environment and setbacks. To persist in the phase, entrepreneurs should take actions to eliminate the influence of negative emotions. At this stage, entrepreneurs take the initiative to acquire affirmation from others and enhance their entrepreneurial confidence. Meanwhile, when their products/services are not launched and tested by the market, entrepreneurs can easily ignore negative feedback on their entrepreneurial ideas. At this stage, entrepreneurs selectively listen to suggestions and remain themselves in a positive emotional state. Therefore, at this stage, the motivation level of entrepreneurs has increased.

In the launch stage, entrepreneurs perceive the positive emotion of high arousal but also the negative emotion of low arousal. The main reasons are the boredom of repetition after the successful launch and the frustration of facing some challenges, such as product failure or financing difficulties. Therefore, at this stage, the motivation level of entrepreneurs has declined. To smoothen the transition and hold entrepreneurship, entrepreneurs use corresponding behavior strategies, such as starting a new experience or seeking stronger social support to overcome negative emotions and obtain positive emotions. A friend or family member's affirmation cannot sufficiently dispel doubts about one's career. Entrepreneurs need to know what drives them to continue to work hard, such as self-actualization, autonomy or the passion of entrepreneurship. We observe that entrepreneurs are not driven by financial performance. Entrepreneurs see the entrepreneurial process as a process of growth, happiness and satisfaction.

In the post-launch stage, the predictability of entrepreneurial path increases, and entrepreneurs frequently experience positive and negative emotions. Entrepreneurs adjust their emotions by controlling their entrepreneurial behaviors to perceive highly intense positive emotions. Achieving business goals is time-consuming, and assessing the progress of the goals is difficult. Thus, entrepreneurs attempt to create exciting experiences to gain positive emotions by seeking positive feedback, launching new products or services, considering the growth of enterprises and copying the behaviors in the pre-launch stage. The motivation level of entrepreneurs who can overcome negative emotions and enter the post-launch stage will rise and eventually tend to stabilize. Based on the above analysis and simulation, as well as the emotion trend in Figure 2, the trend chart of the relationship between entrepreneurial motivation and emotion is shown in Figure 3. 


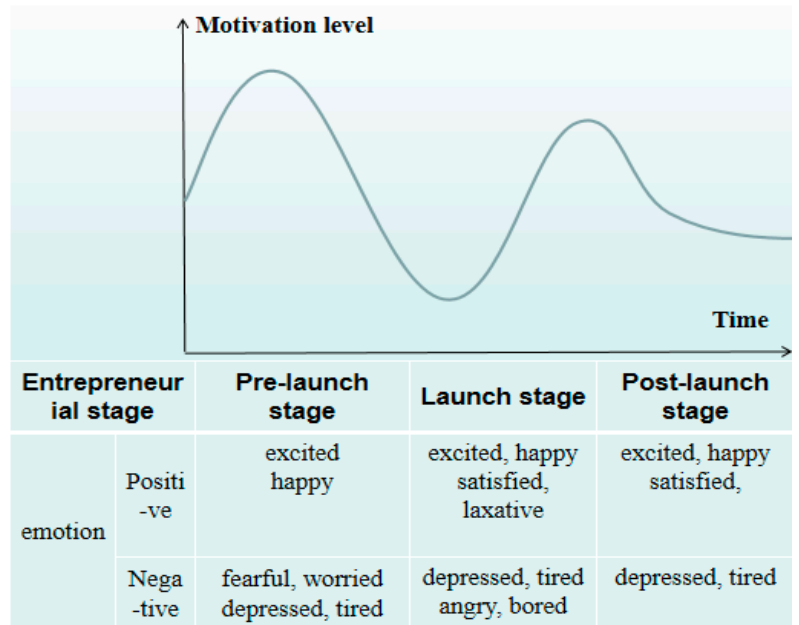

Figure 3. Entrepreneurial motivation trends.

Proposition 2. Acquiring positive emotional experience is an indispensable source of sustained entrepreneurial motivation for entrepreneurs. Meanwhile, the level of entrepreneurial motivation varies in different stages of entrepreneurship.

\subsection{Role of Positive Emotions in the Process of Entrepreneurship}

Emotion influences behavior through cognition, and emotion influences cognition through intuitive and analytical cognitive models [11,61]. On the basis of the above data analysis, we obtain three core resources in the process of entrepreneurship, namely, entrepreneurial willingness, resources and ability. Amongst them, entrepreneurial willingness is one of the best predictors of entrepreneurial behavior [62]. Meanwhile, entrepreneurial resources and ability have important strategic significance for the growth of startups. Therefore, this chapter analyses the influence of entrepreneurial emotion on the three core activities and explores the cognitive model to reveal the mechanism of positive emotion on entrepreneurial process.

\subsubsection{Effect of Positive Emotions on the Formation of Entrepreneurial Willingness}

Previous studies have emphasized that entrepreneurial cognition plays an important role in the formation of entrepreneurial willingness. However, these studies are static analysis. Entrepreneurs' behavior decision making will inevitably be affected by emotion; thus, it is based on the interaction of rationality and emotion. Accordingly, emotion plays an important role in the periodic change of entrepreneurial intention. Therefore, entrepreneurial intention should be explored in combination with entrepreneurial emotion, which will help in understanding the dynamic changes of entrepreneurial intention. On the basis of Wang Chongming's (2004) [63] classification of entrepreneurial intention, this study analyses entrepreneurial emotion and intention. To clarify the relationship between entrepreneurial emotion and intention, each dimension of entrepreneurial intention and emotion is regarded as a 'node circle'. Amongst them, the intersection of different node circles is the number of codes that represent these node relationships in microblog or blog semantic analysis. By coding six samples, the positive emotion and entrepreneurial willingness of each stage of entrepreneurship are shown in Figure 4, and the statistical summary of reference points of entrepreneurial willingness is shown in Table 7. 


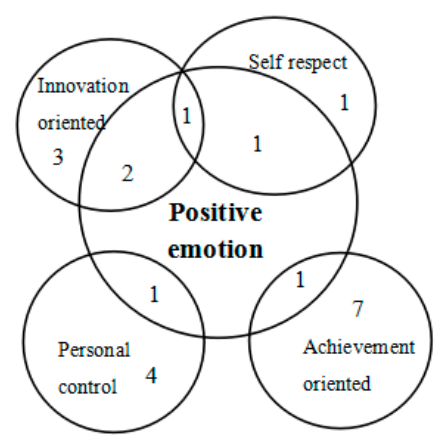

Pre-launch stage

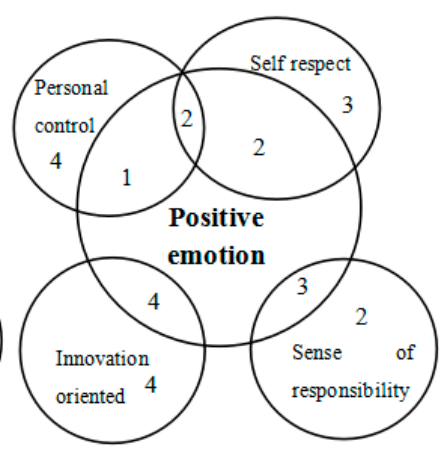

Launch stage

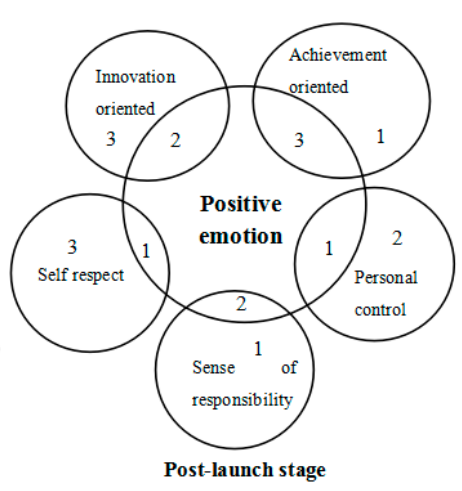

Post-launch stage

Figure 4. Positive emotions and entrepreneurial willingness.

Table 7. Code of entrepreneurial intention dimension.

\begin{tabular}{|c|c|c|c|}
\hline $\begin{array}{c}\text { Entrepreneurial } \\
\text { Intention Dimension }\end{array}$ & Source Number & Reference Points & Typical Quotes \\
\hline Innovation oriented & 10 & 16 & $\begin{array}{l}\text { 'Like this way of life, so the atmosphere can } \\
\text { stimulate my enthusiasm and creativity'. }\end{array}$ \\
\hline Achievement oriented & 8 & 17 & $\begin{array}{l}\text { 'Everyone has their own entrepreneurial dream } \\
\text { and hopes to challenge themselves again'. }\end{array}$ \\
\hline Self-respect & 6 & 17 & $\begin{array}{l}\text { 'Do something to make your life more valuable } \\
\text { and meaningful'. }\end{array}$ \\
\hline Personal control & 5 & 15 & $\begin{array}{c}\text { 'Make your favorite products in the } \\
\text { way you like'. }\end{array}$ \\
\hline Sense of responsibility & 6 & 9 & $\begin{array}{l}\text { 'My sense of responsibility is multiplied by } \\
\text { everyone's enthusiasm. Only by doing a good } \\
\text { project can I repay my expectation'. }\end{array}$ \\
\hline
\end{tabular}

As shown in Figure 4, positive emotion can explain the formation of entrepreneurial intention to some extent, and it is different in various stages of entrepreneurship. In the pre-launch stage, entrepreneurs have high achievement orientation. However, the explanation of positive emotion is limited because this stage is highly uncertain and dynamic, even entrepreneurs with positive emotion cannot evaluate the degree of goal realization or even the goal. At this stage, the positive emotion affects the innovation orientation and self-respect dimensions of entrepreneurs. People with positive emotions are more likely to take the initiative to obtain social support and increase the recognition of social members to gain self-respect. As Du Mengjie mentioned, 'Do something that makes my life more valuable and meaningful.' Entrepreneurs with positive emotions can store and extract more positive information in the process of entrepreneurship and discover new entrepreneurial fields in the information [61]. Individuals with positive emotions have a good perception of the outside world [64]. When entrepreneurs find a potential opportunity, they will think that the opportunity is positive and good; hence they will be more willing to engage in innovative behaviors to promote innovation orientation. As Zhang Liaoyuan mentioned, 'It's a magic thing to create a place that doesn't exist. It's full of passion driving force before it's started.'

In the launch stage, entrepreneurs with positive emotions have a strong sense of responsibility to promote the formation of their entrepreneurial willingness. On the one hand, they should respond positively to the support of friends, customers and even investors. $\mathrm{Xu}$ Xiaohui mentioned that 'Everyone's enthusiasm makes me feel more responsible, and I can only expect to return if I do a good job in the project'. On the other hand, entrepreneurs should be responsible for their team and employees. As Guo Ziwei mentioned, 'On the day when the company is founded, I have responsibility, I should be responsible for the supporters, and more importantly, for the team.' After the product is launched, feedback from customers and friends will be obtained. For positive feedback, entrepreneurs with positive emotions will actively optimize and innovate their products/services. For negative feedback, entrepreneurs with positive emotions can use divergent thinking to view problems from 
different perspectives. As mentioned by Wang Kuncheng, 'Lack of resources teaches small companies how to be more innovative. Any simple problem or any small purchase forces us to find ways to reduce prices in the shortest time, but also to achieve the best results.' Entrepreneurs believe that entrepreneurship is to do what they like to do and to make their lives valuable and meaningful to obtain satisfaction, that is, entrepreneurs with positive emotions can have high self-respect and personal control. Chaike said, 'Entrepreneurship is not a shortcut to earn fame and wealth, you just like such freedom, comfort and focus, like such a lifestyle, and go all out to fight for yourself.'

In the post-launch stage, entrepreneurs have shifted from focusing on short-term, achievable goals to long-term goals. Du Mengjie mentioned that 'We hope our platform can produce ideas and products that change the world in the future, and we hope that we can become the world in ourselves'. Entrepreneurs with positive emotions have a high achievement orientation, and they constantly explore new products and services. As Wang Kuncheng mentioned, 'We focus on exploring the most novel, the most high-end enjoyment is also the constant pursuit we have been exploring, which can be changed and improved around this core.'

Here, we also found that entrepreneurs tend to use intuitive processing to see potential business opportunities and develop entrepreneurial willingness. Similar to Du Mengjie's entrepreneurial process, it is based on his experience and preferences to prompt him to quickly identify potential entrepreneurial opportunities. Choosing to be a crowdfunding website is related to one's limited knowledge and personal experience; it is entirely based on one's experience, which is a quick heuristic response. Du Mengiie's positive emotions, especially the entrepreneurial passion, enable him to see the opportunities and challenges of the crowdfunding industry and form entrepreneurial willingness. Therefore, we propose the following proposition.

Proposition 3. Positive emotion helps entrepreneurs form entrepreneurial intention through intuitive processing, and entrepreneurs tend to have different dimensions of entrepreneurial intention in different stages of entrepreneurship.

\subsubsection{Effect of Positive Emotion on the Acquisition of Entrepreneurial Resources}

Entrepreneurial resources are the sum of tangible and intangible resources to achieve entrepreneurial goals [65]. Obtaining the resources needed for the operation of an enterprise is an important step in creating a new enterprise. Such resources include not only financial resources but also social network ones. Entrepreneurial emotion, especially positive emotion, plays an important role in the acquisition of entrepreneurial resources. Positive emotion mainly comes from the spiral construction effect of positive emotion $[11,66]$. The theory of extension construction based on positive emotions is shown in Figure 5. Positive emotions can expand the immediate thinking action category of individuals. This expansion of the mind-action category provides the resources to make one sustainable, which in turn provides potential for personal growth and development by generating positive or adaptive emotional-cognitive-behavioral spirals [66].

We find that entrepreneurs who have infectious emotions and express a high degree of positive emotions towards their entrepreneurial ideas can obtain positive reactions from investors, customers and employees, which in turn promote the success of entrepreneurship [67]. To obtain entrepreneurial resources, entrepreneurs infect investors, relatives, or friends and obtain their support with passion and dreams. Positive emotions can also promote entrepreneurs to be more confident in negotiations and creatively solve problems, such that both sides of the negotiation can establish a friendly negotiation atmosphere and obtain satisfactory negotiation results [68]. For example, as a serial entrepreneur, Chaike has experienced eight entrepreneurial failures. However, his optimism and entrepreneurial passion for the Internet industry have made him rise again. This enthusiasm has infected other members of his entrepreneurial team. The team's feelings and tacit understanding have gradually 
increased, and the team has been in a state of full of fighting spirit. In the end, he obtained 180 million yuan of financing from Sequoia, Bertelsmann, and other investors.

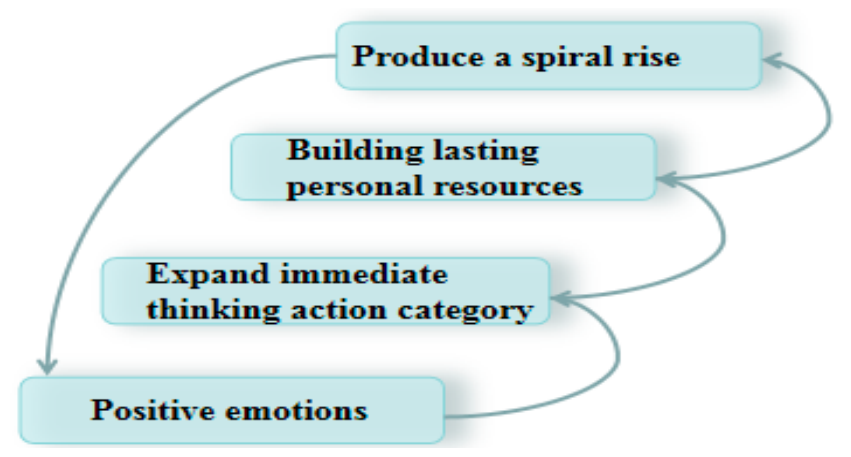

Figure 5. Theory of expansion and construction of positive emotion.

Social networks are also an important source of entrepreneurial resources [69]. These resources can be obtained through market transactions or informal relationship networks; however, in the initial stage of highly uncertain business prospects and performance, entrepreneurs can only rely on reciprocity and trust in personal relationship networks [70]. Entrepreneurs with positive emotions are more likely to actively participate in social activities, enhance social connections and thus enhance social adaptability, which helps expand their social network and improve the quality of their relationship network [71]. Social networks can also be used as a type of identity resource that transmits values and spread attitudes and emotions. When entrepreneurs acquire more positive experience from expanding their social networks, the consolidation and development of social networks will be promoted. Therefore, positive emotions and social networks have a spiral interaction, which is conducive to the acquisition of entrepreneurial resources. For example, the birth of Chanyouji originated from a trip to Cambodia by Guo Ziwei. At the beginning of the venture, Guo Ziwei obtained a million yuan of financing and attracted team members who are also fond of travelling. In the most difficult period of funds, Ctrip also obtained 35 million yuan of financing. In sum, we propose the following proposition.

Proposition 4. Positive emotions help entrepreneurs obtain entrepreneurial resources through analytical processing. At the same time, the expansion of positive emotion to the category of individual instant thinking action is also conducive to the construction of sustainable entrepreneurial resources.

\subsubsection{Effect of Positive Emotion on the Expansion of Entrepreneurial Ability}

The entrepreneurial ability of entrepreneurs is the key resource to drive the successful development of entrepreneurial activities [72]. For the code of entrepreneurial ability, we refer to the research of Mei and Long (2010) [73]. We also divide entrepreneurial ability into six dimensions, in which opportunity identification and development abilities reflect the dynamic ability in the uncertain environment of entrepreneurship, whereas strategic, organizational management, relationship and commitment abilities are static ability. Through coding six samples, the relationship between positive emotion and entrepreneurial ability is obtained, as shown in Figure 6. The statistical summary of reference points of entrepreneurial intention ability is shown in Table 8.

On the basis of the data analysis, positive emotions in different stages affect the use and expansion of entrepreneurship to a certain extent, and differences exist in the various stages of entrepreneurship. In the pre-launch stage, positive emotion plays a certain role in shaping the ability of opportunity recognition. Fredrickson (2002) indicated that positive emotions can expand cognitive scope and improve the ability to detect events or stimuli, enhance entrepreneurs' awareness of entrepreneurial opportunities and promote them to actively search for opportunities, thereby immediately identifying entrepreneurial opportunities [66]. For example, although Chai Ke has eight failure experiences, 
with his passion for entrepreneurship, he quickly discovered new areas of entrepreneurship from the positive information he had obtained. Positive emotions can significantly promote divergent thinking, make individuals have strong thinking flexibility and promote the ability of individuals to solve problems creatively; moreover, individuals with high divergent thinking can view problems from different perspectives [74,75]. Then, the entrepreneurial opportunity development ability is stimulated. As mentioned by Wang Kuncheng, 'With extreme excitement, the details of a new brand start to be remembered, and then spread to systematic thinking including packaging design, user experience, office decoration, personnel matching, hard and wide design'. In addition, positive emotion has a strong explanatory power to the relationship ability at this stage. Entrepreneurs with positive emotions will take the initiative to obtain social support and recognition and establish good interpersonal relationships with others. For example, Du Mengjie took the initiative to participate in AIESEC, Leili, China and other organizations and mentioned that 'To know and promote all kinds of creative and passionate people, and to supplement all kinds of knowledge, our work is meaningful and very happy'.
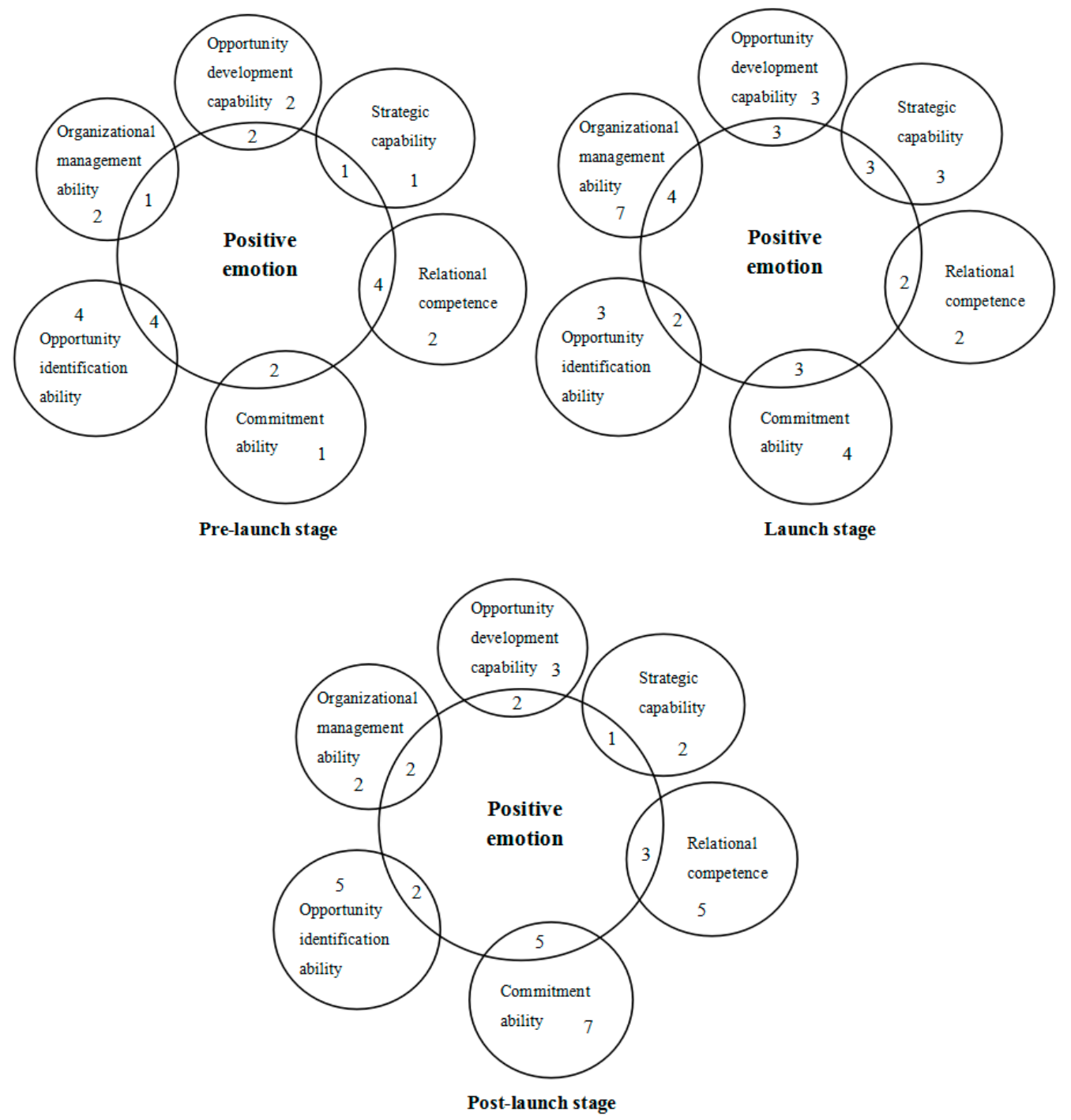

Figure 6. Positive emotions and entrepreneurial ability.

In the launch stage, products/services are launched and tested by the market. However, many problems remain, which results in a large amount of negative feedback. Entrepreneurs with positive emotions can learn from failures. In comparison with individuals with negative emotions, they are more confident and optimistic; thus, they have strong commitment ability. For example, given the 
limited resources and lack of channels, Du Mengjie constantly adjusted the product model after the launch of new products and finally learned from the failure of many projects; he proposed to build a crowdfunding platform focusing on helping young people. In addition, at this stage, entrepreneurs should handle a series of tedious daily organizational management problems, which is conducive to the improvement of their organizational management ability. As Guo Ziwei mentioned, 'In this period of time, team management, company operation and customer service are more pleasant than technical work'.

Table 8. Code of entrepreneurial ability dimension.

\begin{tabular}{|c|c|c|c|}
\hline $\begin{array}{l}\text { Entrepreneurial Ability } \\
\text { Dimension }\end{array}$ & Source Number & Reference Points & Typical Quotes \\
\hline $\begin{array}{l}\text { Opportunity } \\
\text { identification ability }\end{array}$ & 9 & 20 & $\begin{array}{l}\text { 'I want to create a platform for people with } \\
\text { ideas and abilities to realize their dreams'. }\end{array}$ \\
\hline $\begin{array}{c}\text { Opportunity } \\
\text { development capability }\end{array}$ & 7 & 15 & $\begin{array}{l}\text { 'We focus on exploring the most novel and } \\
\text { high-end enjoyment, which we have always } \\
\text { been pursuing'. }\end{array}$ \\
\hline $\begin{array}{l}\text { Organizational } \\
\text { management ability }\end{array}$ & 9 & 20 & $\begin{array}{l}\text { 'In this period of time, the company has } \\
\text { gained more pleasure in operation than in } \\
\text { technical work'. }\end{array}$ \\
\hline Strategic capability & 6 & 9 & $\begin{array}{l}\text { 'At first, I was too dedicated to health, and } \\
\text { now I finally learn to use the logic of the } \\
\text { Internet to do things'. }\end{array}$ \\
\hline Relational competence & 8 & 16 & $\begin{array}{l}\text { 'It's not necessarily investment help. The } \\
\text { advice and resources provided by Mr. Lei } \\
\text { are more important than the } \\
\text { monev invested'. }\end{array}$ \\
\hline Commitment ability & 11 & 21 & $\begin{array}{l}\text { 'At the beginning, the passion for starting a } \\
\text { business gradually changed from an } \\
\text { exposed excitement to an inner persistence } \\
\text { that never gives up'. }\end{array}$ \\
\hline
\end{tabular}

In the post-launch stage, environmental predictability is enhanced, and entrepreneurs accumulate certain experience and ability in the process of entrepreneurship. Positive emotions make entrepreneurs' commitment ability constantly improve. As Wang Kuncheng said, 'In this period of time, I have grown up a lot in all aspects, and the original passion for entrepreneurship has gradually changed from an exposed excitement to an inner never give up insistence'. Moreover, entrepreneurs with positive emotions think that no great danger and threat exist [11], which makes them actively expand useful skills and social networks [66], thereby promoting the development of their relationship ability.

Entrepreneurial ability is constantly developing in the process of entrepreneurship, which should be obtained through processing and systematic thinking. Entrepreneurs with positive emotions can learn from failures, improve the ability of opportunity identification and development, adjust objectives and business ideas in time, integrate resources to adapt to the environment and improve strategic and organizational management abilities in the process. For example, with eight failures, Chaike analyzed the reasons and thought that he did not grasp the rigid needs in the field of health nor understand the media attributes of the product. On the basis of the accumulation of entrepreneurial experience, he finally launched over 100 million downloaded health applications. Moreover, individuals with positive emotions pay more attention to personal health, which makes them more able to handle high and persistent stress [76,77]; thus, their commitment ability can be improved. In addition, entrepreneurs actively expand useful skills and social networks by using the expansion construction theory to promote the development of relationship ability of entrepreneurs, which is also a spiral construction process. In addition, entrepreneurial ability is also obtained through analytical processing. Therefore, we propose the following proposition.

Proposition 5. Positive emotion helps entrepreneurs expand their entrepreneurial ability through analytical processing, and the dimensions of entrepreneurial ability vary in different entrepreneurial stages. 


\subsection{Entrepreneurial Emotion and Results}

This study finds that entrepreneurial behavior is seldom driven by economic motivation. From the perspective of positive psychology, entrepreneurship is the process of obtaining happiness and satisfaction, and existing research often use the economic benefits of entrepreneurship to measure the entrepreneurial performance. However, for startup enterprises, the realisation of wealth goal is distant, and they may face the risk of wealth loss. Therefore, this study considers emotional return as a performance dimension parallel to economic return.

From the economic perspective, several differences exist in the performance of entrepreneurs. Guo Ziwei's team won a total of 35 million yuan of financing from Ctrip in the first three years of its establishment. In 2014, its products became the iPhone prototype demonstration application for offline stores in the App Store. Zhang Liaoyuan's team has only established three squirrels for more than two years, and its nut series has ranked first in the sales volume of the entire network. In 2014, 'double 11' achieved a daily sales volume of 102 million yuan. Chaike's healthcare application is the first and most influential women's menstrual health management software in China, with more than 80 million registered users and more than 4.2 million daily active users. Conversely, Xu Xiaohui's team has successfully established its initial brand, but the later capital chain is broken. At 2013, Xiaohui's company was entirely acquired by Vanke Chengpin in the form of cash and share exchange.

From the perspective of the pursuit of happiness, a certain similarity exists in the emotional return that entrepreneurs with positive emotions obtain happiness and growth in the process of entrepreneurship. For example, Du Mengjie succeeded in his first venture, but he believed that 'Maybe a project will win a lot of profits and achieve the secular so-called "success, but maybe a year later we went out of business. In any case, this process is worthy of gratitude and aftertaste. I feel very satisfied to spend a stage of my life like this'. Wang Kuncheng's entrepreneurial process has been a steady and slow growth. He mentioned that 'In the entrepreneurial process, for the first time, he knew that he could grow up in a calm way and gain experience in solving numerous small problems'. Thus, although not rich, the spirit is always full. Chai Ke, who experienced eight entrepreneurial failures, believes that 'Every entrepreneurship can bring huge growth to himself. During this period, I have grown a lot in all aspects. At the beginning, the passion of entrepreneurship gradually changed from an exposed excitement to an inner never give up insistence'. On this basis, we propose the following proposition.

Proposition 6. Entrepreneurship brings economic benefits and emotional returns to entrepreneurs. In terms of economic returns, there are great differences between entrepreneurs; in terms of emotional returns, there is a certain similarity in the emotional returns obtained by entrepreneurs with positive emotions, that is, the entrepreneurial process brings them happiness and growth.

\section{Discussion}

\subsection{Conclusions}

Entrepreneurship is a dynamic process. Entrepreneurial decision will lead to the change of entrepreneurs' emotions, and then affect the subsequent behavior. Therefore, on the basis of the perspective of positive psychology, this study analyses entrepreneurial emotions, cognition, and behavior in different stages of entrepreneurship, forming the research framework of this study. Through NVivo software and emotion dictionary, this study analyses more than 27,000 Weibos of six entrepreneurs and reconstructs the entrepreneurial process. We also discuss the driving force and mechanism of positive feeling for entrepreneurs to insist on entrepreneurship and establishes the conclusion. The model is shown in Figure 7. 


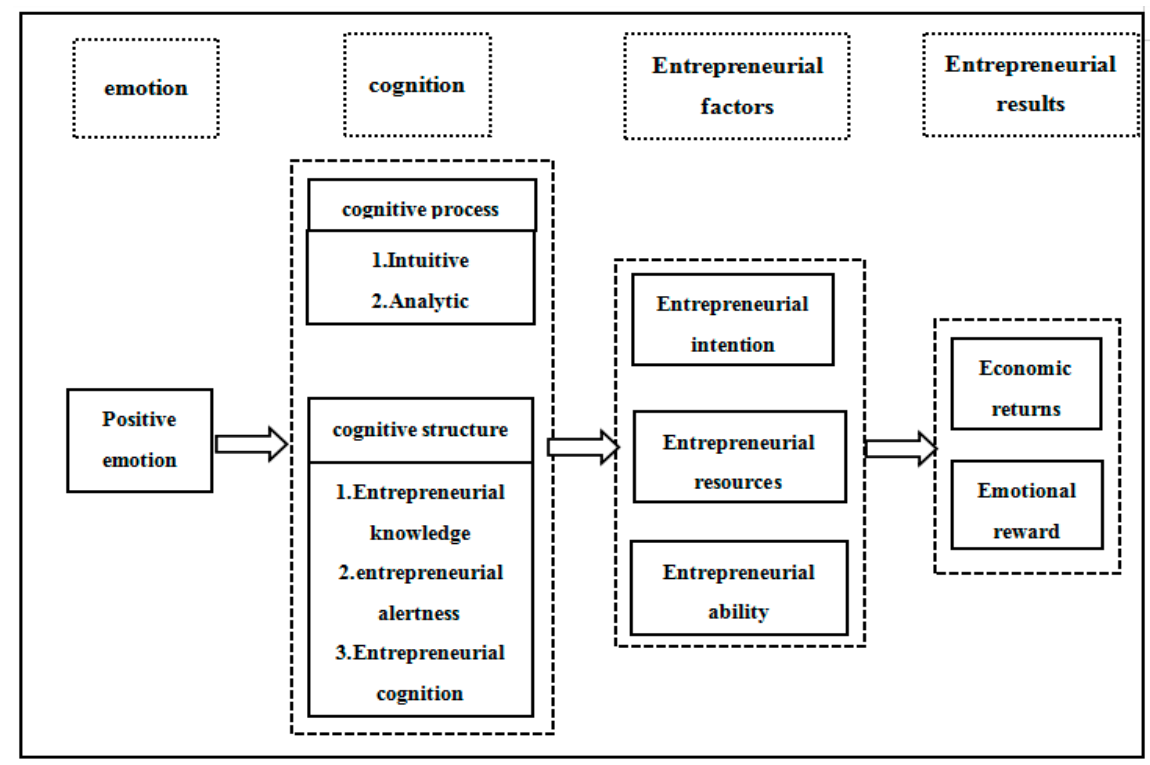

Figure 7. Role model of positive emotion in entrepreneurial process.

Firstly, this study explains the sustained effort behavior of entrepreneurs in the process of entrepreneurship. Entrepreneurship is a long-term process, facing uncertainty of economic return and risk of failure. Therefore, maximizing wealth is not the greatest driving force for entrepreneurs to continue their entrepreneurship. In different stages of entrepreneurship, entrepreneurs experience different entrepreneurial emotions. Entrepreneurs can maximize positive emotions or overcome negative emotions through some strategies; thus, they can persist in entrepreneurial activities, which reveals the mechanism behind entrepreneurs' persistence in entrepreneurship. On the basis of the perspective of positive psychology, this study analyses the entrepreneurial process and finds that entrepreneurship is a process of obtaining happiness and satisfaction. Therefore, obtaining positive emotional experience is an indispensable source of sustained entrepreneurial motivation for entrepreneurs; however, the level of entrepreneurial motivation varies in different stages of entrepreneurship.

Secondly, this study discusses the mechanism of positive emotion. On the one hand, positive emotion can promote the formation of entrepreneurial intention, access to entrepreneurial resources and expansion entrepreneurial ability. In different stages, the positive emotions of entrepreneurs can explain the different dimensions of entrepreneurial intention through intuitive processing and promote the expansion of entrepreneurial resources and entrepreneurial ability through analytical processing. On the other hand, in the process of entrepreneurship, entrepreneurs with positive emotions have high entrepreneurial alertness and creative cognition and constantly accumulate entrepreneurial knowledge to promote the development of entrepreneurial intention, resources and ability.

Ultimately, in the process of entrepreneurship, emotional return is a performance dimension that measures the results of entrepreneurship in parallel with economic return. Entrepreneurship entails economic and emotional returns to entrepreneurs. Specifically, although positive emotions cannot bring the same economic benefits to entrepreneurs, they can acquire similar emotional returns, that is, happiness and growth.

\subsection{Contributions}

The theoretical contributions of this study are mainly reflected in the following aspects. Firstly, we expand the sources of entrepreneurial motivation of existing entrepreneurs. In the field of economic management, entrepreneurial behavior has long been studied from the perspective of performance motivation. Research on entrepreneurial activities has also been involved in the field of psychology. However, the research on the combination of the two should be enriched. This study 
integrates the theoretical perspective of mainstream entrepreneurship and social psychology, focusing on entrepreneurs' emotion and entrepreneurial behavior in the initial stage and investigates the emotion and behavior in the entrepreneurial process. By regarding the nonmonetary psychological reward as the entrepreneurial motivation mechanism parallel to the performance incentive, this study analyses the economic and non-economic driving forces of entrepreneurial activities; investigates the relationship amongst entrepreneurial motivation, emotion and entrepreneurial behavior; and further complements and improves the existing entrepreneurial motivation theory.

Secondly, we promote the exploration of the mechanism of positive emotion in the process of entrepreneurship. Existing studies have discussed the influence of emotion on entrepreneurial behavior; however, the in-depth analysis of the influence path is lacking [11]. In this study, positive emotion, an important cognitive factor, is embedded in the process of entrepreneurship, which deeply shows the key role and significance of positive emotion in the behavior decision making of entrepreneurs and provides a new perspective for exploring the behavior decision making of entrepreneurs to adhere to entrepreneurship. We find that entrepreneurs can obtain positive emotions by taking certain action strategies and then generate sustained effort behavior. Acquiring positive emotions is an important means to ensure the continuous investment of new entrepreneurs.

Finally, we enrich the research on entrepreneurial emotion from the perspective of entrepreneurial persistence. Existing research on entrepreneurial well-being explores the outcome variables based on the fact that 'emotion influences individual cognition and behavior'; however, studies are limited to the cognition (e.g., risk perception) and behavior (e.g., initiative) of entrepreneurs [48] and seldom involve the persistence of entrepreneurs in the process of entrepreneurship. The conclusion of this study partly explains the phenomenon that 'although most entrepreneurs end up in failure, they continue to do so', which brings us new insights into 'what benefits or experiences can entrepreneurship bring to entrepreneurs in addition to financial benefits and mental growth'.

\subsection{Managerial Implications}

This study also has certain practical significance. On the one hand, entrepreneurs are encouraged to establish a healthy and positive outlook on entrepreneurship and consciously build a positive emotional system. This study holds that in comparison with mature enterprises, the entrepreneurial activities of new enterprises contain more excitement, passion and sense of achievement, which will stimulate more innovation and vitality of entrepreneurs. Moreover, obtaining positive emotions becomes an indispensable part of the entrepreneurial process. Therefore, we should use the attitude of learning and growth to contain the past, use positive emotions to overcome the hardships of entrepreneurship and promote entrepreneurs to gain happiness and growth to achieve entrepreneurial goals and self-worth.

Conversely, this study advocates the transformation of entrepreneurial activities from single-dimension economic goal orientation to equally emphasise on economic and happiness incentives. By studying the dynamic mechanism and decision-making behavior of entrepreneurs in the initial stage, this study clearly realizes that maximizing wealth is not the only source of motivation for entrepreneurs to start a business, and perceiving the happiness and satisfaction brought by entrepreneurship often becomes the internal driving force for entrepreneurs to continue their business. Therefore, entrepreneurs are encouraged to set scientific goals, make reasonable attribution, flexibly adjust their entrepreneurial strategic decisions, strive to improve their ability to balance in an uncertain environment and achieve a strong combination of wealth value and self-worth.

\subsection{Limitations}

As an exploratory case study, this work contains some limitations. Firstly, in terms of data collection, this study takes Weibo and blogs as the main data sources. Although they can well describe the real-time emotion and behavior of the entrepreneurial process, Weibo and blogs do not record all the information of entrepreneurs' personal experience, and a risk exists that entrepreneurs beautify 
their content to gain social favor. In other words, most of the information from such resources skews toward positive side by nature. In the future, some entrepreneurs can be tracked dynamically or conduct in-depth interviews with them to further obtain objective and accurate data. Secondly, in terms of research methods, some subjectivity exists in the sample selection and data analysis. In the future, quantitative analysis can be introduced to improve the reliability of research. We can learn from the experimental method and empirical sampling method of emotional state and behavior in psychology and use them in entrepreneurship research. In this manner, the relationship between entrepreneurial emotion and behavior can be explored to verify relevant research topics. Thirdly, when this study discusses the relationship mechanism between emotion and entrepreneurial behavior, it mainly analyses from the valence level, that is, considering the influence of positive emotion without distinguishing the different influences of emotional arousal on entrepreneurial process. In the future, we should further improve the emotion cognition behavior model. In the analysis of entrepreneurial emotion trend chart, the method adopted integrates the basic emotion dictionary. However, Weibo language is relatively wide, including symbols and network language. Thus, a complete emotion semantic analysis dictionary should be constructed to analyse the emotion process.

Author Contributions: Conceptualization, X.S. and S.L.; Methodology, S.Z. and L.L.; Software, L.L; Validation, X.S., S.L. and S.Z.; Formal analysis, S.L. and L.L.; Investigation, X.S.; Resources, S.Z.; Data curation, L.L.; Writing —original draft preparation, S.L. and L.L.; Writing_-review and editing, S.L.; Visualization, X.S. and S.L.; Supervision, X.S. and S.Z.; Project administration, X.S.; Funding acquisition, X.S. All authors have read and agreed to the published version of the manuscript.

Funding: This research was funded by the National Natural Science Foundation Project "Social Entrepreneurship from the Perspective of Institutional Theory: from Induction to Realization" [grant number: 71872074], The National Natural Science Foundation Project "Research on Social Entrepreneurial Motivation and Decision-making Behavior" [grant number: 71572202], the Fundamental Research Funds for the Central Universities [grant number: 19JNKY08], and The APC was funded by Sun Yat-sen University.

Conflicts of Interest: The authors declare no conflict of interest.

\section{References}

1. Hulbert, B.; Gilmore, A.; Carson, D. Sources of opportunities used by growth minded owner managers of small and medium sized enterprises. Int. Bus. Rev. 2013, 22, 293-303. [CrossRef]

2. Shane, S.; Venkataraman, S. The Promise of Entrepreneurship as a Field of Research. Acad. Manag. Rev. 2000, 25, 217-226. [CrossRef]

3. Rahman, M.; Uddin, M.; Lodorfos, G. Barriers to Enter into Foreign Markets: Evidence from SMEs in an Emerging Economy. Int. Mark. Rev. 2017, 34, 68-86. [CrossRef]

4. Uy, M.A.; Foo, M.D.; Song, Z. Joint effects of prior start-up experience and coping strategies on entrepreneurs' psychological well-being. J. Bus. Ventur. 2013, 28, 583-597. [CrossRef]

5. Rauch, A.; Frese, M. Born to Be an Entrepreneur? Revisiting the Personality Approach to Entrepreneurship. Organ. Front. 2007, 41-65.

6. Benz, M. Entrepreneurship as a non-profit-seeking activity. Int. Entrep. Manag. J. 2006, 5, 23-44. [CrossRef]

7. Cooper, A.C.; Artz, K.W. Determinants of satisfaction for entrepreneurs. J. Bus. Ventur. 1995, 6, 439-457. [CrossRef]

8. Li, X.; Ye, W.; Zhu, K. Shackles and struggles of cages: Regional relationship culture and relationship strategy of start-ups. Manag. World 2016, 10, 88-102.

9. Su, Y.; Wu, N.; Zhou, X. Entrepreneurial process model from the perspective of system - Multi case study based on grounded theory. Nankai Manag. Rev. 2017, 1, 181-192.

10. Rindova, V.; Barry, D.; Ketchen, D.J. Entrepreneuring as Emancipation. Acad. Manag. Rev. 2009, 34, 477-491. [CrossRef]

11. Baron, R.A. The Role of Affect in the Entrepreneurial Process. Acad. Manag. Rev. 2008, 33, 328-340. [CrossRef]

12. Dijkhuizen, J.; Gorgievski, M.; van Veldhoven, M.; Schalk, R. Feeling successful as an entrepreneur: A job demands-Resources approach. Int. Entrep. Manag. J. 2016, 12, 555-573. [CrossRef] 
13. Welpe, I.M.; Spörrle, M.; Grichnik, D.; Michl, T.; Audretsch, D.B. Emotions and Opportunities: The Interplay of Opportunity Evaluation, Fear, Joy, and Anger as Antecedent of Entrepreneurial Exploitation. Entrep. Theory Pract. 2012, 36, 69-96. [CrossRef]

14. Baum, J.R.; Locke, E.A. The relationship of entrepreneurial traits, skill, and motivation to subsequent venture growth. J. Appl. Psychol. 2004, 89, 587. [CrossRef]

15. Carsrud, A.; Nnback, M.B. Entrepreneurial Motivations: What Do We Still Need to Know? J. Small Bus. Manag. 2011, 49, 9-26. [CrossRef]

16. Kuratko, D.F.; Hornsby, J.S.; Naffziger, D.W. An examination of owner's goals in sustaining entrepreneurship. J. Small Bus. Manag. 1997, 35, 24.

17. Baumol, W.J. Entrepreneurship: Productive, unproductive, and destructive. J. Political Econ. 1990, 98, 893-921. [CrossRef]

18. Gilad, B.; Levine, P. A behavioral model of entrepreneurial supply. J. Small Bus. Manag. 1986, $24,45$.

19. Douglas, E.J.; Shepherd, D.A. Entrepreneurship as a utility maximizing response. J. Bus. Ventur. 2000, 15, 231-251. [CrossRef]

20. Hessels, J.; van Gelderen, M.; Thurik, R. Entrepreneurial aspirations, motivations, and their drivers. Small Bus. Econ. 2008, 31, 323-339. [CrossRef]

21. Van Praag, C.M.; Cramer, J.S. The roots of entrepreneurship and labour demand: Individual ability and low risk aversion. Economica 2001, 68, 45-62. [CrossRef]

22. Segal, G.; Borgia, D.; Schoenfeld, J. The Motivation to Become an Entrepreneur. Int. J. Entrep. Behav. Res. 2005, 11, 42-57. [CrossRef]

23. Krueger, N.F., Jr.; Reilly, M.D.; Carsrud, A.L. Competing models of entrepreneurial intentions. J. Bus. Ventur. 2000, 15, 411-432. [CrossRef]

24. Ryan, R.M.; Deci, E.L. When rewards compete with nature: The undermining of intrinsic motivation and self-regulation. Intrinsic Extrinsic Motiv. 2000, 13-54.

25. Hagner, D.; Davies, T. Doing my own thing: Supported self-employment for individuals with cognitive disabilities. J. Vocat. Rehabil. 2002, 17, 65-74.

26. Arnold, N.L.; Seekins, T. Self-employment: A process for use by vocational rehabilitation agencies. J. Vocat. Rehabil. 2002, 17, 107-113.

27. McGee, J.E.; Peterson, M.; Mueller, S.L.; Sequeira, J.M. Entrepreneurial Self-Efficacy: Refining the Measure. Entrep. Theory Pract. 2009, 33, 965-988. [CrossRef]

28. Mcmullen, J.S.; Shepherd, D.A. Entrepreneurial Action and the Role of Uncertainty in the Theory of the Entrepreneur. Acad. Manag. Rev. 2006, 31, 132-152. [CrossRef]

29. Curran, T.; Hill, A.P.; Appleton, P.R.; Vallerand, R.J.; Standage, M. The psychology of passion: A meta-analytical review of a decade of research on intrapersonal outcomes. Motiv. Emot. 2015, 39, 631-655. [CrossRef]

30. Houlfort, N.; Fernet, C.; Vallerand, R.J.; Laframboise, A.; Guay, F.; Koestner, R. The role of passion for work and need satisfaction in psychological adjustment to retirement. J. Vocat. Behav. 2015, 88, 84-94. [CrossRef]

31. Huang, Y.; Zhu, S. Research on the impact mechanism of entrepreneurship policy supply on entrepreneurship behavior of entrepreneurs-Empirical Analysis Based on GEM report panel data. Sci. Technol. Manag. 2018, 4, 100-110.

32. Mitchell, R.K.; Busenitz, L.; Lant, T.; McDougall, P.P.; Morse, E.A.; Smith, J.B. Toward a Theory of Entrepreneurial Cognition: Rethinking the People Side of Entrepreneurship Research. Entrep. Theory Pract. 2002, 27, 93-104. [CrossRef]

33. Ronald, K.M. The Composition, Classification and Creation of New Venture Formation Expertise; The University of Utah David Eccles School of Business: Salt Lake City, UT, USA, 1994.

34. Olson, P.D. Entrepreneurship: Process and Abilities. Am. J. Small Bus. 1985, 10, 25-31. [CrossRef]

35. Krueger, N.F., Jr.; Day, M. Looking Forward, Looking Backward: From Entrepreneurial Cognition to Neuroentrepreneurship. In Handbook of Entrepreneurship Research; Springer: New York, NY, USA, 2010.

36. Zhang, M.; Ren, S. How do entrepreneurs shape entrepreneurial ability from events? A case study of continuous Entrepreneurship Based on event system theory. Manag. World 2018, 34, 140-155.

37. Kickul, J.; Gundry, L.K.; Barbosa, S.D.; Whitcanack, L. Intuition Versus Analysis? Testing Differential Models of Cognitive Style on Entrepreneurial Self-Efficacy and the New Venture Creation Process. Entrep. Theory Pract. 2009, 33, 439-453. [CrossRef] 
38. Baron, R. Cognitive mechanisms in entrepreneurship: Why and when entrepreneurs think differently than other people. J. Bus. Ventur. 1998, 13, 275-294. [CrossRef]

39. Yang, L.; Jiang, C. Research on emotion priming. Psychol. Sci. 2005, 28, 321-323.

40. Sarasvathy, S.D. Causation and Effectuation: Toward a Theoretical Shift from Economic Inevitability to Entrepreneurial Contingency. Acad. Manag. Rev. 2001, 26, 243-263. [CrossRef]

41. Cardon, M.S.; Foo, M.D.; Shepherd, D.; Wiklund, J. Exploring the Heart: Entrepreneurial Emotion Is a Hot Topic. Entrep. Theory Pract. 2012, 36, 1-10. [CrossRef]

42. Baron, R.A.; Tang, J. The role of entrepreneurs in firm-level innovation: Joint effects of positive affect, creativity, and environmental dynamism. J. Bus. Ventur. 2011, 26, 60. [CrossRef]

43. He, L.; Zhang, Y.; Song, Z. Research on the relationship between entrepreneurial mood and entrepreneurial behavior tendency. Res. Dev. Manag. 2017, 3, 13-20.

44. Russell, J.A. A circumplex model of affect. J. Personal. Soc. Psychol. 1980, 39, 1161-1178. [CrossRef]

45. Foo, M.D. Emotions and Entrepreneurial Opportunity Evaluation. Entrep. Theory Pract. 2011, 35, $375-393$. [CrossRef]

46. Hayton, J.C.; Cholakova, M. The role of affect in the creation and intentional pursuit of entrepreneurial ideas. Entrep. Theory Pract. 2012, 36, 41-68. [CrossRef]

47. Shepherd, D.A.; Covin, J.G.; Kuratko, D.F. Project failure from corporate entrepreneurship: Managing the grief process. J. Bus. Ventur. 2009, 24, 588-600. [CrossRef]

48. Yu, X.; Meng, X.; Cai, L.; Zhao, H. Entrepreneurship and well-being: A review of research and prospects for the future. Foreign Econ. Manag. 2018, 40, 30-44.

49. Seligman, M.E.; Csikszentmihalyi, M. Positive psychology. An introduction. Am. Psychol. 2000, 55, 5. [CrossRef]

50. Hahn, V.C.; Frese, M.; Binnewies, C.; Schmitt, A. Happy and Proactive? The Role of Hedonic and Eudaimonic Well-Being in Business Owners' Personal Initiative. Entrep. Theory Pract. 2012, 36, 97-114. [CrossRef]

51. Uy, M.A.; Sun, S.; Foo, M.D. Affect spin, entrepreneurs well-being, and venture goal progress: The moderating role of goal orientation. J. Bus. Ventur. 2017, 32, 443-460. [CrossRef]

52. Li, G.; Mao, J. Case selection and research strategy: A summary of China enterprise management case and qualitative research forum (2014). Manag. World 2015, 2, 133-136.

53. Miles, M.; Michael, H.A. Analysis of Qualitative Data: Method and Practice; Chongqing University Press: Chongqing, China, 2008.

54. Yin, R. Case study research. Design and methods. J. Adv. Nurs. 2010, 44, 108.

55. Strauss, A.L.; Corbin, J.M. Grounded Theory in Practice; Sage Publications: Thousand Oaks, CA, USA, 1997.

56. Kato, S.; Wiklund, J. Doing Good to Feel Good-A Theory of Entrepreneurial Action Based in Hedonic Psychology. Front. Entrep. Res. 2011, 33, 123-137.

57. Foo, M.D.; Uy, M.A.; Baron, R.A. How do feelings influence effort? An empirical study of entrepreneurs' affect and venture effort. J. Appl. Psychol. 2009, 94, 1086-1094. [CrossRef] [PubMed]

58. Li, R. An empirical analysis of the psychological motivation of entrepreneurial behavior. China Soft Sci. 2008, 4, 88-97. [CrossRef]

59. Kahneman, D. Maps of Bounded Rationality: Psychology for Behavioral Economics. Am. Econ. Rev. 2003, 93, 1449-1475. [CrossRef]

60. Diener, E. Subjective well-being. The science of happiness and a proposal for a national index. Am. Psychol. 2000, 55, 34. [CrossRef]

61. Zhou, X.; Jiang, F.; Chen, Y. Positive emotion theory of entrepreneur entrepreneurship cognition. China's Ind. Econ. 2014, 8, 135-147.

62. Duan, J.; Tian, X.; Xue, X. Effect reasoning: Entrepreneurial decision making under uncertainty. Manag. Rev. 2010, 2, 53-58.

63. Fan, W.; Wang, C. A study on the influencing factors of entrepreneurial tendency. Psychol. Sci. 2004, 5, 1087-1090.

64. Schwarz, N.; Clore, G.L. Mood, Misattribution, and Judgments of Well-being: Informative and Directive Functions of Affective States. J. Personal. Soc. Psychol. 1983, 45, 513-523. [CrossRef]

65. Gu, Q.; Liang, D.; Zhao, W. The construction and analysis of the theoretical model of entrepreneurial motivation. Sci. Technol. Prog. Countermeas. 2005, 12, 93-94.

66. Fredrickson, B.L. Positive emotions. Handb. Posit. Psychol. 2002, 120-134. 
67. Hatfield, E.; Cacioppo, J.T.; Rapson, R.L. Emotional contagion. In Studies in Emotion and Social Interaction; Cambridge University Press: Cambridge, UK, 1994.

68. Kopelman, S.; Rosette, A.S.; Thompson, L. The three faces of Eve: Strategic displays of positive, negative, and neutral emotions in negotiations. Organ. Behav. Hum. Decis. Process. 2006, 99, 81-101. [CrossRef]

69. Adler, P.S. Social Capital: Prospects for a New Concept. Acad. Manag. Rev. 2002, 27, 17-40. [CrossRef]

70. Uzzi, B. The Sources and Consequences of Embeddedness for the Economic Performance of Organizations: The Network Effect. Am. Sociol. Rev. 1996, 61, 674-698. [CrossRef]

71. Nahapiet, J.; Ghoshal, S. Chapter 6-Social Capital, Intellectual Capital, and the Organizational Advantage. Knowl. Soc. Cap. 1998, 23, 242-266.

72. Zhang, Y.; Wang, X. Empirical research on previous experience, learning style and entrepreneurship. Manag. Sci. 2011, 3, 1-12.

73. Mei, D.; Long, Y. Research on the relationship between entrepreneurship and innovation type in uncertain environment. Sci. Res. 2010, 9, 1413-1421.

74. Lu, J.; Liu, W.; He, W. The influence of emotional state on students' creativity. J. Psychol. 2002, 4, 51-56.

75. Vosburg, S.K. The Effects of Positive and Negative Mood on Divergent-Thinking Performance. Creat. Res. J. 1998, 11, 165-172. [CrossRef]

76. Sonja, L.; Laura, K.; Ed, D. The benefits of frequent positive affect: Does happiness lead to success? Psychol. Bull. 2005, 131, 803-855.

77. Carver, C.S.; Scheier, M.F. Optimism, pessimism, and self-regulation. Optim. Pessim. Implic. Theory Res. Pract. 2001, 31-51.

(C) 2020 by the authors. Licensee MDPI, Basel, Switzerland. This article is an open access article distributed under the terms and conditions of the Creative Commons Attribution (CC BY) license (http://creativecommons.org/licenses/by/4.0/). 